\title{
KAJIAN PENCOCOKAN KEPALA ARCA BUDDHA CANDI BOROBUDUR TAHAP II
}

\author{
Hari Setyawan, Agus Hendratno, Marsis Sutopo, Jati Kurniawan, Puji Santosa, \\ Irawan Setiyawan \\ Balai Konservasi Borobudur \\ Email : sivanata_raja@yahoo.com
}

\begin{abstract}
Abstrak : Maksud dilaksanakananya Kajian Pencocokan Kepala arca adalah mencocokan 56 kepala arca Dhyani Buddha dengan 247 tubuhnya pada struktur Candi Borobudur. Setelah diselesaikannya Kajian Pencocokan Kepala Arca Buddha Candi Borobudur tahap I tahun 2015, beberapa metode pencocokan telah diformulasikan dan diuji. Metode pencocokan menggunakan ikonometri dan ikonografi belum dapat digunakan untuk mencocokan karena presisi satuan ikonometri arca tersebut. Metode ultrasound velocity dan magnetic susceptibility juga telah terbukti tidak efektif dalam mencocokkan kepala dan tubuh arca.

Pada Kajian Pencocokan Kepala Arca Buddha Candi Borobudur Tahap II, metode pencocokan menggunakan tipe material batu andesit yang merupakan bahan arca diaplikasikan. Hal tersebut berdasar pada prinsip bahwa arca dibuat dari batu/ monolith, artinya arca hanya ada satu tipe batu tanpa sambungan pada sebuah arca batu. Pendekatan atau pencocokan tipe material tersebut kemudian disinkronkan dengan data XRF (X-Ray Flouresence) yang telah diambil pada kesemua kepala arca dan sebagian besar tubuh arca tanpa kepala. Sementara hasil pencocokan tipe material bahan arca, menghasilkan 6 tipe yang didasarkan pada tipe material kepala arca yang tersimpan pada kantor Balai Konservasi Borobudur. Tipologi material yang dilakukan berhasil mengerucutkan pencocokan dengan populasi terkecil antara kepala dan tubuh arca pada tipe 6. Dengan demikian fokus pencocokan akan dimulai dari tipe 6 dengan cara mencocokkan beberapa kepala arca pada tubuh arca secara langsung. Pencocokan dengan metode tipe material telah mendapatkan dua kepala arca yang cocok dengan tubuhnya.
\end{abstract}

Kata kunci : pencocokan kepala arca, tipologi material arca, XRF.

Abstract: The purpose of this study is to match the 56 heads of Dhyani Buddha statues with the 247 bodies without head on the structure of Borobudur Temple. After the completion of the Study of Head Matching Buddha Statue of Borobudur Temple phase I in 2015, several matching methods have been formulated and tested. The matching methodology using iconometry and iconography can not be used because of the precision of the statue's iconometric units. The use of ultrasound velocity and magnetic susceptibility have also been shown to be ineffective in matching the head and body of the statue.

In the Study of Head Matching Buddha Statue of Borobudur Temple Phase II, the matching method using the type of andesite stone material which is the material of the statue is applied. It is based on the principle that the statue is made from one block of stone (a monolith). Approach or matching of the material type is then synchronized with XRF (X-Ray Flouresence) data that has been taken on all the head of the statue and most of the body of the statue without head. While the results of matching material types of statues, produce 6 types based on the type of statue material material stored in Borobudur Conservation Office. The typology of the material has succeeded in giving possible matching groups with the smallest population between the head and body of the statue in type 6 . Thus the focus of matching will start from type 6 by matching some statue heads on the body of the statue directly. Matching by material type method has earned two head statues that match the body.

Keyword: Head Matching Buddha Statue, material type of the statue, XRF

\section{PENDAHULUAN}

\subsection{Latar Belakang}

Setelah dipugarnya Candi Borobudur untuk yang kedua kalinya pada tahun 1983, tidak berarti semua permasalahan yang berkaitan dengan pelestariannya dapat diselesaikan dengan baik. Salah satu permasalahan yang belum terselesaikan di antaranya berkaitan dengan arca Dhyani Buddha Candi Borobudur yang menyangkut kelengkapan anatomi arca. Secara eksplisit disampaikan bahwa permasalahan tersebut muncul karena masih ada kepala arca Dhyani Buddha Candi Borobudur yang belum bisa dikembalikan pada struktur candi. Hal ini karena kepala arca tersebut ditemukan terpisah dari tubuhnya tanpa adanya petunjuk, catatan, maupun referensi yang jelas menyangkut posisi asli dari kepala arca tersebut. 
Dari keseluruhan jumlah arca Dhyani Buddha yang berjumlah 504 buah, saat ini masih dijumpai 228 arca Buddha berkepala dan 247 buah arca Dhyani Buddha tanpa kepala. Sementara itu, kepala arca Buddha yang disimpan di Balai Konservasi Borobudur berjumlah 56 buah. Jumlah relung kosong maupun stupa teras kosong/ tanpa dijumpai arca adalah sejumlah 29 buah. Kondisi tersebut memerlukan adanya upaya pelestarian, salah satunya dengan cara mencocokkan kepala arca dengan tubuh arca yang berada pada pagar langkan ataupun stupa teras. Pencocokan arca tidak bisa dilakukan dengan cara langsung, namun dengan cara melakukan penelitian secara lebih mendalam pada kepala arca dan tubuh arca. Hal ini untuk menghindari kesalahan pemasangan yang akan mengurangi nilai penting dari arca tersebut. Melalui kajian ini, diaplikasikan berbagai metode yang dapat digunakan dalam melakukan pencocokan kepala arca.

Metode-metode dan pendapat dari para ahli kemudian dirumuskan dalam bentuk rekomendasi yang nantinya akan ditindaklanjuti dalam bentuk kegiatan fisik. Kegiatan fisik tersebut terutama bertujuan untuk mencocokkan dan memasang kepala arca Buddha pada tubuh arca yang berada di atas struktur candi.

\subsection{Rumusan Masalah}

Berdasarkan uraian pada latar belakang dan tinjauan pustaka, maka permasalahan yang akan ditindaklanjuti dalam Kajian Pencocokan Kepala Arca Buddha Candi Borobudur Tahap II adalah mengetahui efektifitas metode pencocokan tahap I dan mencari metode pencocokan yang ilmiah dan lebih efektif. Sehingga di kemudian hari dapat dikembalikan setidaknya sebagian kecil dari kepala arca yang masih tersimpan di kantor Balai Konservasi Borobudur.

\subsection{Tujuan}

Berdasarkan rumusan permasalahan di atas maka tujuan yang dirumuskan dan akan diselesaikan melalui Kajian Pencocokan Arca Buddha Candi Borobudur Tahap II adalah :

1. Melanjutkan pengukuran dengan metode XRF pada tubuh arca yang berada pada struktur candi yang belum terselesaikan pada tahap I.

2. Melakukan uji coba pencocokan menggunakan metode magnetic susceptibility untuk mengetahui efektifitasnya.
3. Membuat tipologi berdasarkan tekstur/tipe material pada kepala dan tubuh arca.

4. Mencocokan kepala dan tubuh arca dengan metode tipe material yang diperkuat dengan data XRF.

\section{METODE}

Untuk mencapai tujuan dan mendapatkan manfaat dari pelaksanaan Kajian Pencocokan Kepala Arca Candi Borobudur Tahap II maka metode dan alur kajian yang diformulasikan adalah sebagai berikut :

1. Penelusuran literatur dan studi pustaka.

Dilakukan dengan maksud untuk mencari, mengetahui, dan mempelajari data-data dan gambar-gambar menyangkut arca Dhyani Buddha Candi Borobudur.

2. Observasi lapangan.

Observasi lapangan dilakukan untuk melihat kondisi arca di kantor Balai Konservasi Borobudur dan pada struktur Candi Borobudur. Hal ini dilakukan untuk menentukan posisi pengukuran dan analisis arca.

3. Pelaksanaan.

\section{Pengukuran}

Pengukuran yang dimaksud adalah pengukuran unsur material batu andesit yang merupakan bahan arca menggunakan XRF. Selain itu, juga dilakukan tipologi/pengelompokan material berdasarkan tipologi kepala arca dengan acuan yang telah dibuat oleh Prof. Hans Liesens dan Dr. Esther Liesens dari CICS Jerman.

\section{Pendokumentasian}

Pendokumentasian menggunakan video mikroskop dilakukan pada beberapa tubuh arca tanpa kepala. Namun demikian pendokumentasian kegiatan juga dilakukan pada tiap metode yang diaplikasikan pada kepala dan tubuh arca.

\section{Pengambilan Data Teknis Arca}

Untuk melakukan pencocokan kepala dan tubuh arca Dhyani Buddha, maka data teknis yang diambil pada kepala maupun tubuh arca untuk dicocokkan di antaranya adalah, ciri fisik berupa keterawatan objek, warna material, kekompakan material, kandungan unsur mineral, kandungan magnetik material, dan tekstur material. 
4. Analisa dan evaluasi data

Analisa dan evaluasi data dilakukan guna mencocokkan dan mensikronkan data setelah tipologi material diselesaikan. Selanjutanya untuk mencocokan digunakan data XRF yang akan memperkuat kesamaan unsur material arca.

5. Rekomendasi

Rekomendasi merupakan tahap akhir dari Kajian Pencocokan Kepala Arca Buddha Candi Borobudur tahap II. Dalam tahap ini direkomendasikan metode yang sesuai untuk pencocokan kepala arca.

Pada tahap penelusuran literatur dan studi pustaka dapat dilakukan dengan mencari pustaka yang sesuai khususnya menyangkut ikonografi dan ikonometri arca Buddha khususnya Candi Borobudur. Selain itu, studi pustaka juga dilakukan pada kajian-kajian yang pernah dilakukan sebelumnya mengenai ikonometri arca Buddha. Arca Buddha yang dimaksud dala hal ini adalah arca yang berasal dari Kerajaan Mataram Kuna Periode Jawa Tengah. Sehingga data ikonometri bisa digunakan sebagai data pembanding dalam melakukan pencocokan kepala arca Buddha di Candi Borobudur. Beberapa acuan pustaka yang digunakan dalam kajian ini dapat berupa prinsipprinsip ikonografi arca Buddha secara umum dari berbagai kitab di India yang menyampaikan informasi mengenai ikonografi dan ikonometri arca Buddha.

Data ikonografi dan ikonometri dari berbagai sumber pustaka tersebut kemudian dikompilasi dan dijadikan acuan dalam melakukan perbandingan. Beberapa komponen ikonografi arca akan diperbandingkan dengan hasil pengukuran ikonometri arca Buddha Candi Borobudur. Sehingga setelah melakukan pengukuran di lapangan, hasil pengukuran tersebut akan diperbandingkan dengan acuan dari ikonometri arca Buddha berdasarkan kitab dari India.

Pada kajian terdahulu setelah acuan baku ikonometri arca Buddha didapatkan maka tahap selanjutnya adalah melalukan observasi di lapangan. Observasi dilakukan secara langsung pada kepala arca Buddha yang disimpan di kantor Balai Konservasi Borobudur, maupun tubuh arca Buddha yang masih berada pada struktur Candi Borobudur. Pada pelaksanaan observasi juga dilakukan pengukuran dan dokumentasi. Pengukuran dilakukan secara langsung pada objek untuk mengetahui ikonometri kepala arca maupun tubuh arca. Pada pengukuran yang dilakukan satuan yang digunakan adalah $\mathrm{cm}$ (centimeter). Satuan centimeter tersebut kemudian dikonversi menjadi satuan tala, angula, dan yava. Tala adalah satuan pengukuran yang didapatkan dari penjumlahan pada pengukuran panjang garis dahi sampai hidung dan panjang garis hidung sampai batas dagu. Angula adalah satuan pengukuran yang pada konsep dasarnya adalah dengan membagi satuan tala menjadi 12. Sedangkan untuk satuan yava didapatkan dengan membagi angula menjadi 8 . Hal ini penting untuk mendapatkan perbandingan dimensi arca berdasarkan konsep dasar ikonometrinya.

Pengelompokan tipe material arca atau tipolgi material arca dilakukan setelah formulasi tipologi ditetapkan oleh seorang ahli konservasi yang dtugaskan oleh UNESCO untuk memberikan bantuan teknis konservasi batu (UNESCO Expert Mission 2015). Ahli tersebut adalah Prof. Dr. Hans Liesens dan Dr. Esther Liesens dari Cologne Institute of Conservation Science, Jerman. Tipologi yang diformulasikan adalah dengan mengelompokkan kesemua kepala arca Dhyani Buddha yang disimpan di kantor Balai Konservasi Borobudur menjadi 6 tipe batu andesit yang merupakan bahan arca. Tipologi tersebut kemudian digunakan untuk mengelompokkan keseluruh tubuh arca pada struktur Candi Borobudur menjadi 6 kelompok besar (Leisen, 2016).

Selanjutnya setelah tipologi kepala dan tubuh arca berhasil disusun, baru kemudian sinkronisasi data dilakukan. Sinkronisasi data bertujuan untuk membuat justifikasi kesamaan material arca antara kepala dengan tubuhnya, hal ini karena arca merupakan artefak yang monolith sehingga material antara kepala yang patah dengan tubuhnya sudah seharusnya sama. Sinkronisasi tersebut dilakukan dengan menggunakan data unsur material yang diukur menggunakan XRF. Sehingga pada metode kajian ini, tipologi karakter material dan pengukuran menggunakan XRF dilakukan secara bersamaan.

Setelah melalui tahap analisis maka selanjutnya adalah penyusunan rekomendasi kajian. Pada rekomendasi tersebut akan disampaikan hasil dan tindak lanjut dari metode pencocokan yang diaplikasikan maupun metode yang nantinya diaplikasikan untuk kajian selanjutnya. 


\section{REVIEW PUSTAKA}

\subsection{Arca Buddha Pada Candi Borobudur}

Kata arca berasal dari bahasa Inggris yaitu icon, yang berarti gambaran dewa atau orang suci yang dituangkan dalam lukisan, mosaik, pahatan dan sebagainya. Kata icon berasal dari bahasa Yunani eikon yang artinya sama dengan kata-kata berbahasa Sansekerta arca, tanu, rupa, bera dan vigraha. Sehingga kata arca diartikan sebagai gambaran dewa yang dipuja.

Ilmu yang mempelajari arca secara keseluruhan meliputi kegunaan, ikonografi maupun simbol-simbolnya disebut Ikonologi. Ilmu mengenai arca mempunyai cabang-cabang tersendiri, diantaranya adalah Ikonografi dan Ikonometri. Ikonografi sebagai cabang dari ikonologi mempelajari sistem tanda-tanda sebagai penentu identitas arca, sedangkan ikonometri adalah satuan ukuran bagian anatomi arca. Ikonometri merupakan hal yang amat penting bagi seniman pembuat arca karena merupakan ketentuan pokok yang dijadikan pedoman dalam pembuatan arca (Maulana, 1997).

Dalam ilmu Ikonografi, ikonometri dianggap mempunyai arti penting dalam menentukan baik buruknya kualitas sebuah arca. Hubungan ukuran dengan nilai seni dalam Ikonografi sangat erat. Aturan ukuran arcaarca ini terdapat dalam kitab agama. dan masing-masing arca mempunyai ketentuan sendiri, yang didasarkan pada kedudukan dan fungsinya (Rao, 1920)

Candi Borobudur yang merupakan struktur percandian bercorak keagamaan Buddha mempunyai pantheon yang terdiri dari arca Dhyani Buddha yang posisinya berada pada relung pagar langkan dan strupa teras. Arca Dhyani Buddha Candi Borobudur terdiri dari 6 jenis yaitu:
1. Wajrasatva menempati stupa berlubang di teras melingkar (arupadhatu). Arca ini mempunyai sikap tangan dharmacakramudra yang berarti memutar roda dharma (hukum atau ajaran kebenaran).

2. Akshobya (Timur) dengan sikap tangan Bhumisparsamudra, yaitu dengan tangan kanan menyentuh lutut kanan menunjuk kebawah. Sikap ini menggambarkan ketika Buddha sebelum mencapai Bodhi, menjadikan bumi sebagai saksi. Tangan kiri dalam pangkuan, tangan kanan tertelungkup di atasa lutut kanan.

3. Ratna Sambhava (Selatan), dengan sikap tangan Waramudra atau Waradamudra, yaitu sikap memberi berkah atau anugerah, tangan kiri ada diatas pangkuan kaki, dengan tangan kanan di atas lutut dengan telapak menengadah.

4. Amitabha (Barat) dengan sikap tangan Dhyanamudra, yaitu sikap bersamadhi atau memusatkan pikiran. Kedua tanganya di atas pangkuan dengan telapaknya ke atas, sedemikian sehingga ujung kedua ibu jari bersentuhan.

5. Amoghasiddha (Utara) dengan sikap tangan Abhayamudra yaitu sikap tidak takut bahaya. Tangan kiri diletakan di atas pangkuan, lengan bawah kanan diacungkan kedepan, kelima jari mengarah keatas.

6. Wairocana (pusat) di tengah-tengah dengan sikap tangan Witarkamudra, sikap tangan seperti memberikan pengajaran. Yaitu jari telunjuk dan ibu jari tangan kanan disatukan dengan jari yang lain mengarah ke atas.

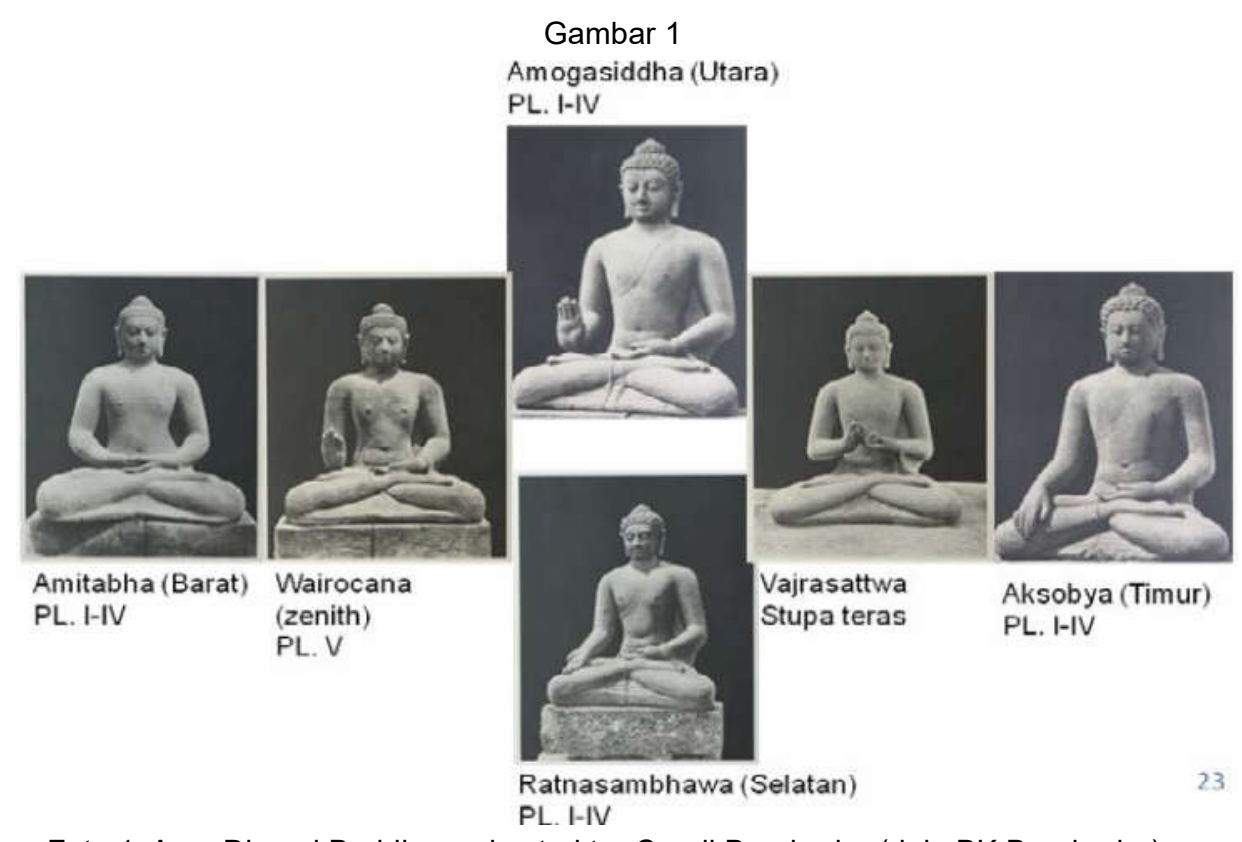

Foto 1. Arca Dhyani Buddha pada struktur Candi Borobudur (dok: BK Borobudur). 
Berdasarkan observasi yang dilakukan pada tahun 2014, maka dapat disampaikan bahwa total jumlah arca pada struktur Candi Borobudur berjumlah 475 buah dengan rincian 228 arca berkepala dan 247 arca tanpa kepala. Berikut ini adalah rincian jumlah arca di struktur Candi Borobudur.

Tabel 1. Jumlah Arca Dhyani Buddha Candi Borobudur.

\begin{tabular}{|c|c|c|c|c|c|c|c|c|c|}
\hline & \multicolumn{8}{|c|}{ Jumlah arca Buddha seharusnya } & \multirow[b]{3}{*}{ jumlah } \\
\hline & \multicolumn{5}{|c|}{ Langkan Tingkat } & \multicolumn{3}{|c|}{ Teras } & \\
\hline & I & II & III & IV & V & VI & VII & VIII & \\
\hline Utara & 26 & 26 & 22 & 18 & 16 & 32 & 24 & 16 & \\
\hline Timur & 26 & 26 & 22 & 18 & 16 & & & & \\
\hline Selatan & 26 & 26 & 22 & 18 & 16 & & & & \\
\hline Barat & 26 & 26 & 22 & 18 & 16 & & & & \\
\hline & 104 & 104 & 88 & 72 & 64 & 32 & 24 & 16 & 504 \\
\hline
\end{tabular}

Tabel 2. Jumlah Arca Dhyani Buddha yang Terpasang saat ini.

\begin{tabular}{|c|c|c|c|c|c|c|c|c|c|}
\hline & \multicolumn{8}{|c|}{ Jumlah arca Buddha yang terpasang saat ini } & \multirow[b]{3}{*}{ jumlah } \\
\hline & \multicolumn{5}{|c|}{ Langkan Tingkat } & \multicolumn{3}{|c|}{ Teras } & \\
\hline & I & II & III & IV & V & VI & VII & VIII & \\
\hline Utara & 23 & 20 & 21 & 17 & 16 & 32 & 24 & 15 & \\
\hline Timur & 22 & 26 & 22 & 17 & 16 & & & & \\
\hline Selatan & 25 & 24 & 21 & 18 & 15 & & & & \\
\hline Barat & 26 & 26 & 19 & 17 & 13 & & & & \\
\hline & 96 & 96 & 83 & 69 & 60 & 32 & 24 & 15 & 475 \\
\hline
\end{tabular}

Tabel 3. Jumlah Arca Dhyani Buddha yang Berkepala.

\begin{tabular}{|c|c|c|c|c|c|c|c|c|c|}
\hline & \multicolumn{8}{|c|}{ Jumlah arca Buddha yang berkepaa } & \multirow[b]{3}{*}{ jumlah } \\
\hline & \multicolumn{5}{|c|}{ Langkan Tingkat } & \multicolumn{3}{|c|}{ Teras } & \\
\hline & $I$ & II & III & IV & $\mathbf{v}$ & VI & VII & VIII & \\
\hline Utara & 8 & 8 & 13 & 10 & 10 & 13 & 3 & 1 & \\
\hline Timur & 7 & 8 & 13 & 13 & 13 & & & & \\
\hline Selatan & 13 & 11 & 11 & 11 & 8 & & & & \\
\hline Barat & 10 & 10 & 10 & 12 & 11 & & & & \\
\hline & 37 & 37 & 47 & 46 & 42 & 13 & 3 & 1 & 227 \\
\hline
\end{tabular}

Tabel 4. Jumlah Arca Dhyani Buddha yang Tanpa Kepala.

\begin{tabular}{|c|c|c|c|c|c|c|c|c|c|}
\hline & \multicolumn{8}{|c|}{ Jumlah arca Buddha tanpa kepala } & \multirow[b]{3}{*}{ jumlah } \\
\hline & \multicolumn{5}{|c|}{ Langkan Tingkat } & \multicolumn{3}{|c|}{ Teras } & \\
\hline & I & II & III & IV & V & VI & VII & VIII & \\
\hline Utara & 15 & 12 & 7 & 7 & 6 & 19 & 21 & 14 & \\
\hline Timur & 15 & 18 & 9 & 4 & 3 & & & & \\
\hline Selatan & 12 & 13 & 10 & 7 & 7 & & & & \\
\hline Barat & 16 & 16 & 9 & 5 & 2 & & & & \\
\hline & 58 & 59 & 35 & 23 & 18 & 19 & 21 & 14 & 247 \\
\hline
\end{tabular}


Tabel 5. Jumlah Arca Dhyani Buddha yang tidak terpasang (Kosong).

\begin{tabular}{|c|c|c|c|c|c|c|c|c|c|}
\hline & \multicolumn{8}{|c|}{ Jumlah arca Buddha yang tidak terpasang (KOSONG) } & \multirow[b]{3}{*}{ jumlah } \\
\hline & \multicolumn{5}{|c|}{ Langkan Tingkat } & \multicolumn{3}{|c|}{ Teras } & \\
\hline & $\mathbf{I}$ & II & III & IV & V & VI & VII & VIII & \\
\hline Utara & 3 & 6 & 1 & 1 & 0 & 0 & 0 & 1 & \\
\hline Timur & 4 & 0 & 0 & 1 & 0 & & & & \\
\hline Selatan & 1 & 2 & 1 & 0 & 1 & & & & \\
\hline Barat & 0 & 0 & 3 & 1 & 3 & & & & \\
\hline & 8 & 8 & 5 & 3 & 4 & 0 & 0 & 1 & 29 \\
\hline
\end{tabular}

Tabel 6. Jumlah Arca Dhyani Buddha yang bukan pasanganya.

\begin{tabular}{|c|c|c|c|c|c|c|c|c|c|}
\hline & \multicolumn{8}{|c|}{ Jumlah arca Buddha bukan pasangannya } & \multirow[b]{3}{*}{ jumlah } \\
\hline & \multicolumn{5}{|c|}{ Langkan Tingkat } & \multicolumn{3}{|c|}{ Teras } & \\
\hline & I & II & III & IV & V & VI & VII & VIII & \\
\hline Utara & 0 & 0 & 1 & 0 & 0 & 0 & 0 & 0 & \\
\hline Timur & 0 & 0 & 0 & 0 & 0 & & & & \\
\hline Selatan & 0 & 0 & 0 & 0 & 0 & & & & \\
\hline Barat & 0 & 0 & 0 & 0 & 0 & & & & \\
\hline & 0 & 0 & 1 & 0 & 0 & 0 & 0 & 0 & 1 \\
\hline
\end{tabular}

Tabel 7. Rekap Jumlah Arca Dhyani Buddha Tahun 2014.

\begin{tabular}{|c|c|c|c|c|c|c|c|}
\hline & Arupadhatu & Pagar V & Pagar IV & Pagar III & Pagar II & Pagar I & Total \\
\hline $\begin{array}{l}\text { Arca Buddha } \\
\text { berkepala }\end{array}$ & 17 & 42 & 46 & 47 & 37 & 37 & 227 \\
\hline $\begin{array}{l}\text { Arca Buddha } \\
\text { tanpa kepala }\end{array}$ & 54 & 18 & 23 & 35 & 59 & 59 & 247 \\
\hline $\begin{array}{l}\text { Kosong tanpa ada } \\
\text { arca }\end{array}$ & 1 & 4 & 3 & 5 & 8 & 8 & 29 \\
\hline Bukan pasangan & 0 & 0 & 0 & 1 & 0 & 0 & 1 \\
\hline & \multicolumn{6}{|c|}{ TOTAL ARCA BUDDHA } & 504 \\
\hline
\end{tabular}

Secara lebih mendetail denah arca Buddha di Candi Borobudur dapat dilihat pada Gambar 1. di bawah ini. Selain itu, hal yang menjadi fokus kajian ini adalah
56 buah kepala arca Dhyani Buddha masih tersimpan di kantor Balai Konservasi Borobudur merupakan bagian dari arca Candi Borobudur yang akan dicocokkan. 


\section{DENAH KELETAKAN ARCA DHYANI BUDDHA CANDI BOROBUDUR}

\section{DENAH KELETAKAN PATUNG BUDDHA CANDI BOROBUDUR}

Mei 2014

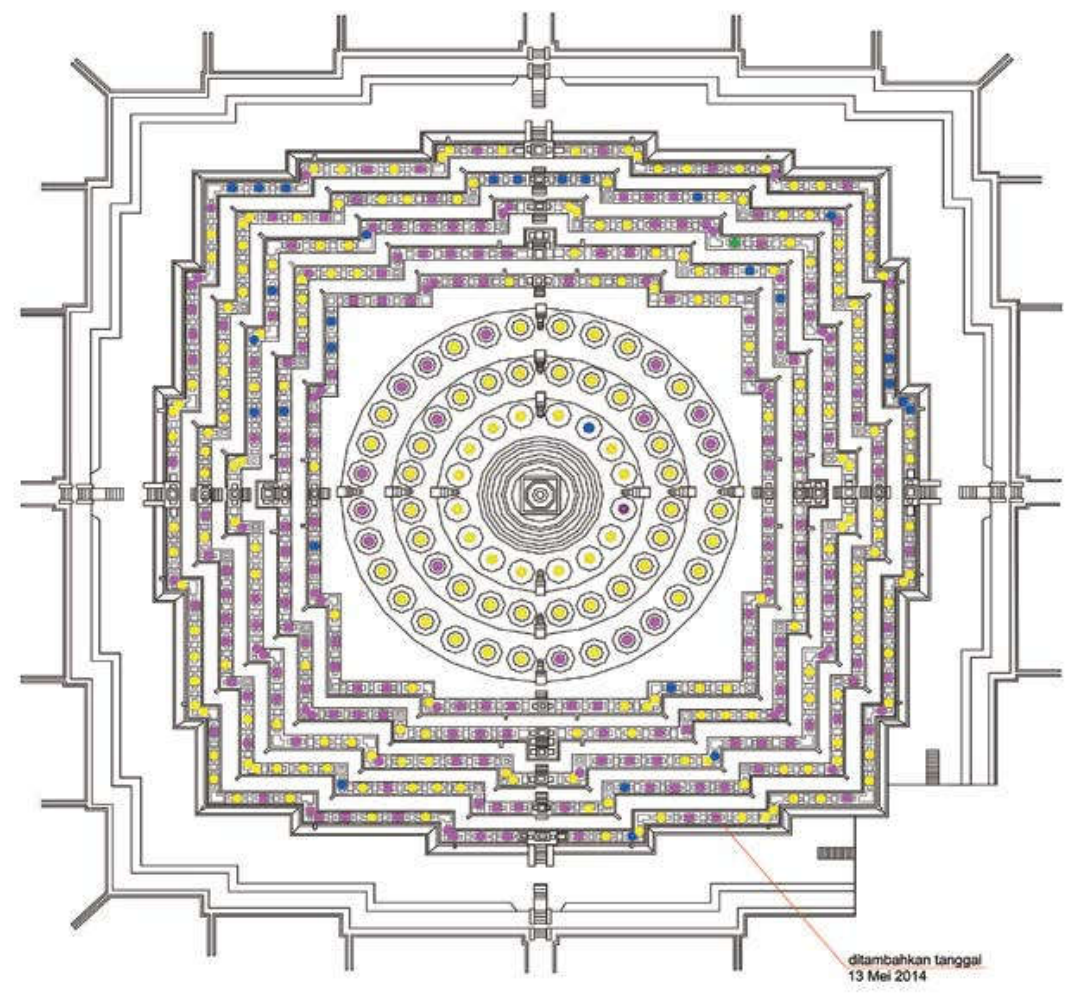

Gambar 1. Denah lokasi arca Dhyani Buddha pada struktur Candi Borobudur (Dok: Tim Kajian,2014)Ikonometri Arca Buddha

Secara lebih mendetail ikonometri adalah pedoman tentang ukuran-ukuran dasar dalam pembuatan arca. Aturan-aturan tersebut dimuat dalam beberapa naskah kitab Cilpacastra, yang antara lain : Cilparatna, Amsumadbhedagama, Karanagama, Vaikhanasagama, Brhat Sambita dan Pratimanalaksanam (Rao, 1920). Namun tidak semua naskah tersebut memuat aturan yang sama, pada umumnya selalu ada perbedaan antara naskah yang satu dengan yang lain.

Dalam naskah-naskah tersebut ada 6 (enam) cara pengukuran bagian arca, yaitu mana (panjang arca), pramana (lebar arca), unmana (tebal arca), parimana (keliling arca), upama (rongga arca) dan lambamana (ukuran vertikal). Adapun satuan ukuran yang sering digunakan dalam pembuatan arca adalah tala dan angula. Istilah Tala secara harfiah berarti telapak tangan, dan dengan pengertian ini dimaksudkan ukuran antara ujung jari tengah hingga akhir dari telapak tangan dekat pergelangan tangan. Ukuran ini dianggap sama dengan panjang muka mulai dari batas rambut (dahi) sampai ke ujung dagu. Kitab Vaikhanasagama, selain menyebut tala juga menyebut kesatuan ukuran lain yaitu angula. Satuan angula merupakan ukuran lebar ruas atas ibu jari atau kirakira 0,75 (tujuh puluh lima perseratus) inci atau sekitar 1,8 (satu delapan persepuluh) $\mathrm{cm}$. Selain kesatuan ukuran tala dan angula, ada kesatuan lain yang lebih kecil yang disebut yava. Menurut Kitab Vaikhanasagama, ukuran satu tala sama dengan 12 angula, dan tiap satu angula sama dengan 8 yava (Rao, 1920).

Berbeda dengan tala, satuan ukuran yang lebih umum digunakan adalah angula. Satuan ukuran angula dibedakan lagi menjadi dua, yaitu mantrangula dan 
dehalabdhangula. Satu angula menurut mantrangula adalah panjang setengah jari tengah dari tokoh yang dipuja atau perancangnya. Dehalabdhangula, ialah ukuran yang diperoleh dengan cara membagi seluruh panjang menjadi 124, 120 atau 116 bagian dari arca yang dibuat (Benerjea, 1941). Hal ini sesuai dengan dengan adanya beberapa klasifikasi arca yang meliputi : nara (manusia-dewa), krura (arca yang mengerikan), asura (raksasa), bala (anak-anak) dan kumara (anak muda). Dalam beberapa jenis arca ini menurut kitab-kitab agama disebutkan ada 10 proporsi arca, yang dapat dikelompokkan menjadi tiga tingkatan, yaitu uttama, madhyama dan adhama. Pertama adalah uttamayaitu ukuran yang utama, terbaik, digunakan bagi arca dewa utama seperti Brahma, Wisnu dan Siwa. Madbyama yaitu ukuran "pertengahan" (cukup, sedang), digunakan untuk para sakti atau dewi. Adhama, ukuran yang tidak baik, yaitu ukuran lebih rendah, digunakan untuk dewa penjaga mata angin atau Lokapala (Rao, 1920).

Berdasarkan konsep agama Buddha, tingkatantingkatan tersebut juga dijumpai. Buddha yang digambarkan sebagai dewa tertinggi menggunakan ukuran Uttamadasatala seperti yang disebutkan dalam kitab Pratimanalaksanam. Dalam kitab tersebut arca Buddha mempunyai ukuran 120 angula (Benerjea, 1941). Sumber yang lain yaitu kitab Kriyasamuccayamenyebutkan bahwa ukuran arca Buddha 124 angula. Tetapi menurut Varahmihira tinggi keseluruhan arca Buddha sama dengan Uttamadasatala yaitu 125 angula, dan menurut Malavya sama dengan 108 angula. Arca-arca Buddha pada umumnya digambarkan dalam sikap duduk samadi atau wajrasana. Sehubungan dengan sikap ini ada petunjuk bahwa arca dalam sikap duduk, jarak antara kedua lututnya sama dengan setengah tinggi keseluruhan dari arca yang digambarkan dalam sikap berdiri. Jadi apabila tinggi arca 124 angula, maka jarak antara kedua lutut dari arca yang digambarkan dalam sikap duduk adalah 62 angula (Rao, 1920).

Menurut naskah Samyaksambuddhabhasita Pratimanalaksanam, panjang muka arca Buddha adalah 13,5 angula yang dibagi menjadi tiga bagian, yaitu dahi, dahi bagian bawah sampai hidung bagian bawah (panjang hidung), dan hidung bagian bawah sampai batas dagu. Ukuran dahi dan panjang hidung adalah empat angula, sedang dari hidung bagian bawah sampai bagian dagu mempunyai ukuran lebih panjang setengah angula menurut terjemahan teks Cina dan satu setengah menurut naskah Sansekerta yang asli. Akan tetapi komentar yang ditemukan dalam kitab Kriyasamuccaya mengenai ikonometeri Buddha, ialah bahwa panjang ketiga bagian dari muka tersebut masing-masing berukuran empat setengah angula. Catatan yang sama menurut kitab Varahamihira mengenai ukuran panjang muka arca Buddha adalah 13 angula (Benerjea, 1941).

\subsection{Material Batu Pada Struktur Candi Borobudur}

Material arca Buddha Candi Borobudur adalah andesit. Adapun mineral yang ada dalam andesit berupa kalium felspar dengan jumlah kurang 10\% dari kandungan felspar total, natrium plagioklas, kuarsa kurang dari 10\%, felspatoid kurang dari 10\%, hornblenda, biotit dan piroksen. Penamaan andesit berdasarkan kepada kandungan mineral tambahannya yaitu andesit hornblenda, andesit biotit dan andesit piroksen. Komposisi kimia dalam batuan andesit terdiri dari unsur-unsur, silikat, alumunium, besi, kalsium, magnesium, natrium, kalium, titanium, mangan, fosfor dan air. Komposisi kimia andesit dapat dilihat pada tabel berikut :

Tabel 8. Komposisi Kimia Andesit (Travis dalam Muryowiharjo, 2005).

\begin{tabular}{|c|c|}
\hline Senyawa & Komposisi (\%) \\
\hline $\mathrm{SiO}_{2}$ & 58,2 \\
\hline $\mathrm{Al}_{2} \mathrm{O}_{3}$ & 17,0 \\
\hline $\mathrm{Fe}_{2} \mathrm{O}_{3}$ & 3,2 \\
\hline $\mathrm{FeO}$ & 3,7 \\
\hline $\mathrm{CaO}$ & 6,3 \\
\hline $\mathrm{MgO}$ & 3,5 \\
\hline $\mathrm{Na}_{2} \mathrm{O}$ & 3,5 \\
\hline $\mathrm{K}_{2} \mathrm{O}$ & 2,1 \\
\hline
\end{tabular}

Berdasarkan sifat fisiknya batu penyusun struktur Candi Borobudur dapat disampaikan sesuai dengan tabel di bawah ini. 
Tabel 9. Sifat fisik sampel batu penyusun Candi Borobudur (Haldoko, 2013).

\begin{tabular}{|l|l|l|l|l|l|}
\hline Parameter & BDR 1 & BDR 2 & BDR 3 & BDR 4 & BDR 5 \\
\hline Densitas (gr/cm ${ }^{3}$ ) & 2,14 & 2,12 & 2,21 & 2,18 & 2,23 \\
\hline Berat Jenis & 2,67 & 2,63 & 2,7 & 2,68 & 2,71 \\
\hline Porositas (\%) & 19,45 & 20,35 & 18,78 & 19,24 & 17,96 \\
\hline Daya serap air (\%) & 10,68 & 10,94 & 9,78 & 10,23 & 9,25 \\
\hline Kekerasan (skala mohs) & $4-6$ & $4-6$ & $4-6$ & $4-6$ & $4-6$ \\
\hline Temperar batu & 45,2 & 44,7 & 47,1 & 45,9 & 48,6 \\
\hline
\end{tabular}

Keterangan :

Nilai tiap-tiap parameter sifat fisik didapatkan dari rata-rata beberapa sampel batu yang warnanya sama.

Dari tabel 9, sifat fisik batu penyusun Candi Borobudur tersebut, densitas sampel BDR 5 (hitam) memiliki nilai yang paling tinggi. Berturut-turut yang memiliki nilai densitas dari besar ke kecil yaitu BDR 3 (abu-abu kehitaman), BDR 4 (kemerahan), BDR 1 (abuabu) dan BDR 2 (abu-abu kecokelatan). Nilai densitas yang lebih tinggi untuk batu yang berwarna gelap dikarenakan sesuai dengan teorinya memiliki kandungan ferro magnesium yang lebih tinggi, sehingga menyebabkan densitasnya menjadi lebih tinggi juga. Nilai berat jenis batu candi mengikuti pola yang sama dengan densitasnya, dimana batu yang memiliki berat jenis yang lebih tinggi, densitasnya juga lebih tinggi. Nilai berat jenis dan densitas ini berbanding terbalik dengan nilai porositas maupun daya serap airnya. Hal ini dikarenakan batuan dengan rapat massa yang lebih besar akan memiliki volume pori yang lebih kecil.
Untuk nilai kekerasan batu, nilai yang didapatkan relatif sama yaitu 4 - 6 skala mohs. Nilai kekerasan 6 skala mohs didapat pada batuan yang tekstur permukannya halus (pori-pori batu kecil), sedangkan nilai kekerasan 4 skala mohs didapat dari andesit yang tekstur permukaannya kasar.

Untuk pengukuran temperatur, andesit dengan warna yang gelap mampu menyerap panas yang lebih besar dibandingkan dengan andesit yang berwarna cerah. Hal ini dikarenakan andesit dengan warna gelap memiliki kandungan ferro magnesium yang lebih tinggi, sehingga kemampuan menyerap dan menyimpan panasnya juga lebih tinggi.

Batu penyusun struktur Candi Borobudur berjenis andesit yang tersusun atas komposisi kimia yang terdiri dari unsur-unsur utama yaitu silikat, alumunium, besi, kalsium, magnesium, natrium, dan kalium.

Tabel 10. Komposisi kimia sampel batu penyusun Candi Borobudur.

\begin{tabular}{|l|l|l|l|l|l|}
\hline Parameter & BDR 1 & BDR 2 & BDR 3 & BDR 4 & BDR 5 \\
\hline $\mathrm{Al}_{2} \mathrm{O}_{3}$ & 16,93 & 17,19 & 14,35 & 15,47 & 13,00 \\
\hline $\mathrm{CaO}$ & 2,68 & 2,60 & 3,89 & 3,50 & 1,96 \\
\hline $\mathrm{FeO}$ & 4,78 & 4,62 & 6,03 & 5,37 & 6,78 \\
\hline $\mathrm{Fe}_{2} \mathrm{O}_{3}$ & 5,14 & 6,71 & 5,97 & 7,53 \\
\hline $\mathrm{MgO}$ & 5,31 & 0,62 & 1,55 & 0,62 & 1,29 \\
\hline $\mathrm{Na}_{2} \mathrm{O}$ & 1,57 & 3,50 & 4,13 & 4,02 & 3,29 \\
\hline $\mathrm{K}_{2} \mathrm{O}$ & 3,81 & 2,35 & 2,65 & 2,88 & 2,73 \\
\hline $\mathrm{SiO}_{2}$ & 2,83 & 59,97 & 58,15 & 58,20 & 56,12 \\
\hline
\end{tabular}

Keterangan :

Sampel yang dianalisis dipilih andesit yang paling baik (tidak ditumbuhi lumut/menggalami penggaraman).

Dari komposisi kimia andesit Candi Borobudur terlihat bahwa andesit yang berwarna cerah relatif memiliki kandungan silika lebih tinggi daripada andesit yang berwarna gelap. Selanjutnya untuk kandungan besi $(\mathrm{Fe})$, andesit yang berwarna gelap memiliki nilai yang lebih tinggi dari andesit yang berwarna terang. Hal ini dikarenakan kandungan mineral mafik (ferro magnesium silikat) yang lebih tinggi sehingga menyebabkan warna yang lebih gelap. 


\section{PELAKSANAAN KAJIAN}

\subsection{Pengukuran Ikonometri Kepala Arca dan Tubuh Arca}

Pengukuran ikonometri bertujuan untuk mengetahui dimensi elemen ikonografi pada kepala arca dan tubuh arca. Dalam melakukan pengukuran ikonometri digunakan konversi ukuran yang disesuaikan dengan kaidah ikonomtri arca Hindhu/Buddha. Konversi ukuran yang digunakan dalam kajian ini adalah tala, angula, dan yava. Tala adalah ukuran panjang wajah dari tumbuhnya rambut hingga janggut. Pengukuran tala biasanya menggunakan acuan ujung jari tengah hingga ujung ibu jari yang direntangkan. Adapun angula merupakan satuan ukuran yang lebih kecil dari tala, 1 tala adalah 12 angula. Sedangkan yava, adalah satuan yang dimensinya disejajarkan dengan 1 butir gandum. Apabila dikonversi 1 angula terdiri dari 8 yava.

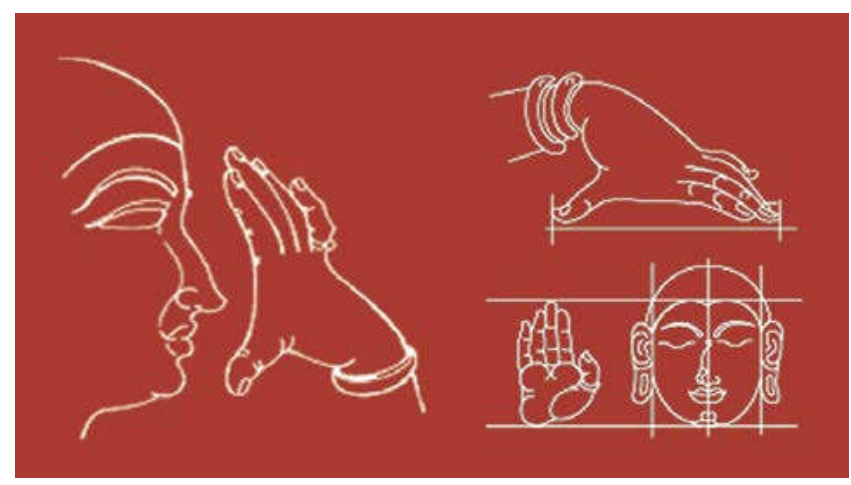

Gambar 2. Satuan ukuran tala (Dok: Kirti Trivedi).

Secara konseptual seperti telah di bahas pada tinjauan pustaka, arca Buddha termasuk golongan Uttam Dasha Tala. Adapun yang termasuk dalam Uttam Dasha Tala di antaranya adalah Brahma, Wisnu Siwa, Ardhanariswara, Mahawira, dan Wasudewa.

Pada langkah awal, pengukuran ikonometri dilakukan dengan mengukur elemen ikonografi pada kepala arca. Satuan yang digunakan adalah centimeter $(\mathrm{cm})$. Setelah kesemua dimensi diketahui, maka langkah selanjutnya adalah melakukan konversi dengan stuan tala, angula, dan yava.

Adapun secara mendetail elemen ikonometriyang di ukur pada kepala arca Budha Candi Borobudur di antaranya adalah rambut, mata, hidung, bibir, telinga, dagu, dan dahi. Kesemua elemen tersebut diharapkan memberikan petunjuk yang dapat digunakan sebagai dasar dalam melakukan pencocokan antara kepala arca dengan tubuh arca yang berada pada struktur Candi Borobudur. Ikonometri yang telah di ukur dari kepala dan tubuh arca diharapkan memberikan perbandingan yang jelas menyangkut dimensi perbandingan ukuran arca sesuai dengan kitab pratimalaksanam ataupun kriyamuccaya.

Pengukuran ikonometri kepala arca Buddha dilakukan pada 56 kepala arca yang disimpan di kantor Balai Konservasi Borobudur. Secara mendetail pengukuran ikonometri pada kepala arca adalah seperti yang disampaikan di bawah ini :

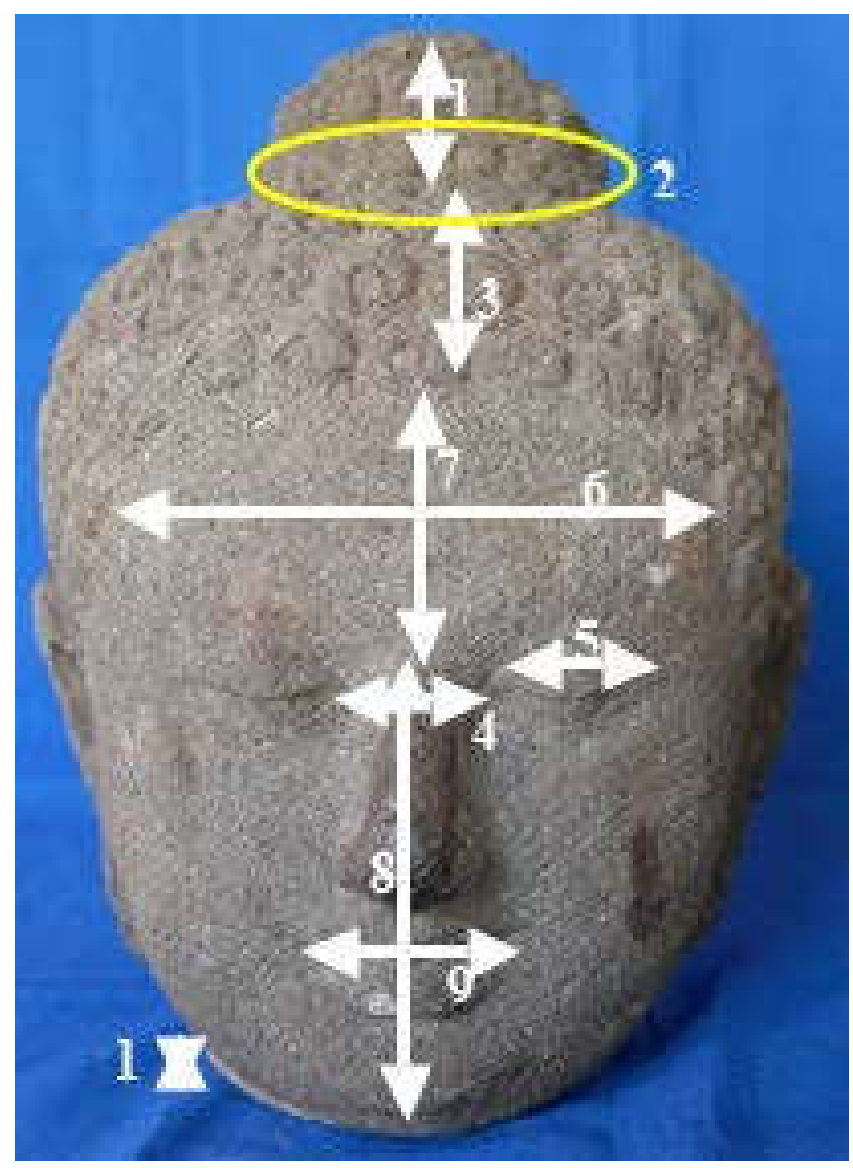

Foto 2. Pengukuran ikonometri pada kepala arca (dok: BK Borobudur). 


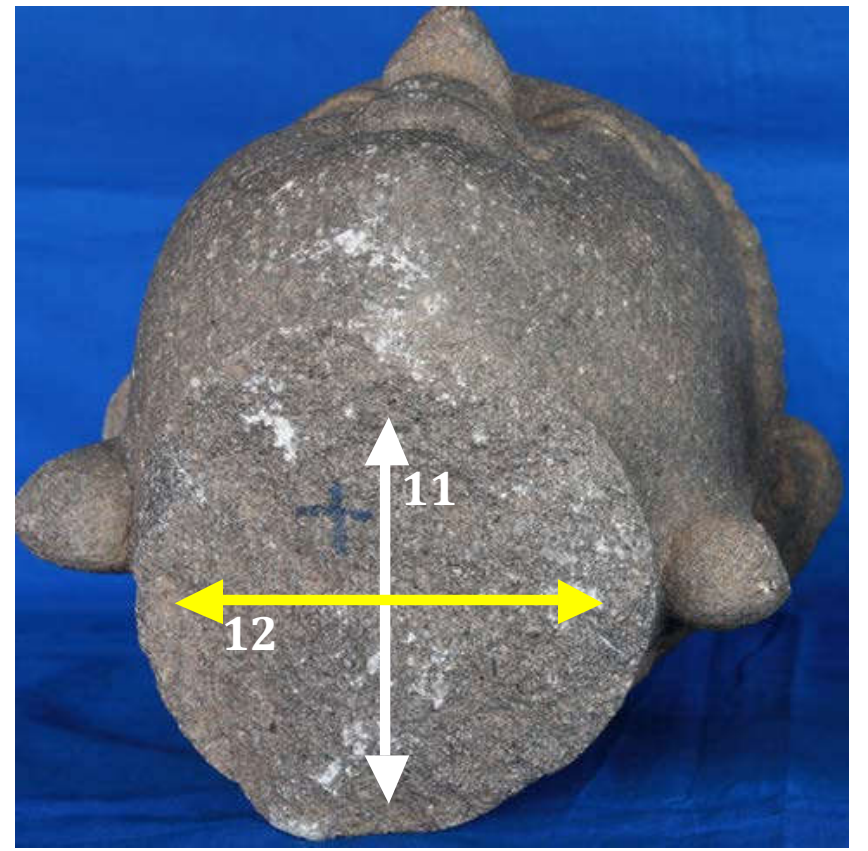

Foto 3. Pengukuran pada leher dan bekas patahan pada leher (dok: BK Borobudur).

\section{Keterangan :}

1. Tinggi usnisa

2. Keliling usnisa

3. Rambut (dari usnisa - dahi)

4. Jarak kelopak mata

5. Lebar kelopak mata

6. Panjang dahi

7. Panjang garis dahi - hidung

8. Panjang garis hidung - dagu

9. Panjang bibir

10. Panjang leher

11. Diameter leher vertikal

12. Diameter leher horizontal

Tabel 11. Rata-Rata Satuan Ukuran Tala, Angula, dan Yava Pada Kepala Arca.

\begin{tabular}{|c|c|c|c|}
\hline No & Tala $\mathbf{( c m )}$ & Anggula $(\mathbf{c m})$ & Yava $(\mathbf{c m})$ \\
\hline 1 & 18,00 & 1,50 & 0,19 \\
\hline 2 & 18,30 & 1,53 & 0,19 \\
\hline 3 & 18,75 & 1,56 & 0,20 \\
\hline 4 & 19,87 & 1,66 & 0,21 \\
\hline 5 & 18,83 & 1,57 & 0,20 \\
\hline 6 & 18,82 & 1,57 & 0,20 \\
\hline 7 & 20,51 & 1,71 & 0,21 \\
\hline 8 & 19,38 & 1,62 & 0,20 \\
\hline 9 & 18,82 & 1,57 & 0,20 \\
\hline 10 & 18,37 & 1,53 & 0,19 \\
\hline 11 & 19,85 & 1,65 & 0,21 \\
\hline 12 & 19,76 & 1,65 & 0,21 \\
\hline
\end{tabular}

\begin{tabular}{|c|c|c|c|}
\hline 13 & 18,45 & 1,54 & 0,19 \\
\hline 14 & 18,78 & 1,57 & 0,20 \\
\hline 15 & 19,03 & 1,59 & 0,20 \\
\hline 16 & 19,15 & 1,60 & 0,20 \\
\hline 17 & 18,56 & 1,55 & 0,19 \\
\hline 18 & 22,17 & 1,85 & 0,23 \\
\hline 19 & 20,20 & 1,68 & 0,21 \\
\hline 20 & 20,08 & 1,67 & 0,21 \\
\hline 21 & 19,60 & 1,63 & 0,20 \\
\hline 22 & 17,70 & 1,48 & 0,18 \\
\hline 23 & 19,90 & 1,66 & 0,21 \\
\hline 24 & 20,86 & 1,74 & 0,22 \\
\hline 25 & 18,20 & 1,52 & 0,19 \\
\hline 26 & & & \\
\hline 27 & 17,61 & 1,47 & 0,18 \\
\hline 28 & 19,63 & 1,64 & 0,20 \\
\hline 29 & 18,40 & 1,53 & 0,19 \\
\hline 30 & 20,10 & 1,68 & 0,21 \\
\hline 31 & 18,80 & 1,57 & 0,20 \\
\hline 32 & 20,08 & 1,67 & 0,21 \\
\hline 33 & 19,30 & 1,61 & 0,20 \\
\hline 34 & 20,50 & 1,71 & 0,21 \\
\hline 35 & 19,26 & 1,61 & 0,20 \\
\hline 36 & 19,27 & 1,61 & 0,20 \\
\hline 37 & 19,40 & 1,62 & 0,20 \\
\hline 38 & 20,65 & 1,72 & 0,22 \\
\hline 39 & 19,17 & 1,60 & 0,20 \\
\hline 40 & 18,35 & 1,53 & 0,19 \\
\hline 41 & 19,60 & 1,63 & 0,20 \\
\hline 42 & 19,57 & 1,63 & 0,20 \\
\hline 43 & 18,70 & 1,56 & 0,19 \\
\hline 44 & 19,33 & 1,61 & 0,20 \\
\hline 45 & 19,00 & 1,58 & 0,20 \\
\hline 46 & & & \\
\hline 47 & & & \\
\hline 48 & 19,01 & 1,58 & 0,20 \\
\hline 49 & 18,40 & 1,53 & 0,19 \\
\hline 50 & 19,38 & 1,62 & 0,20 \\
\hline 51 & 19,89 & 1,66 & 0,21 \\
\hline 52 & 19,45 & 1,62 & 0,20 \\
\hline 53 & 19,00 & 1,58 & 0,20 \\
\hline 54 & 19,50 & 1,63 & 0,20 \\
\hline 55 & 18,22 & 1,52 & 0,19 \\
\hline 56 & 19,30 & 1,61 & 0,20 \\
\hline \multicolumn{4}{|c|}{ RATA-RATA } \\
\hline & 19,26 & 1,61 & 0,20 \\
\hline
\end{tabular}




\subsection{Pengukuran Kandungan Unsur Material Batu}

Pelaksanaan pengukuran kandungan unsur pada material dilakukan dengan menggunakan alat bantu berupa X-Ray Fluoresence (XRF). Aplikasi XRF adalah dengan cara menembakkan langsung sinar x kepada objek kepala arca. Akan tetapi, sebelum dilakukan penembakan prosedur pertama yang harus dipenuhi adalah dengan melakukan kalibrasi pada unit XRF. Aplikasi XRF yang dilakukan pada 1 objek kepala arca Buddha adalah sebanyak 3 kali. Dari hasil pengukuran tersebut, kemudian dilakukan perbandingan dari dua unsur, untuk mendapatkan berbagai kelompok data yang dapat dikelompokkan. Hal ini karena unsur yang dapat diidentifikasi oleh XRF sangat banyak.

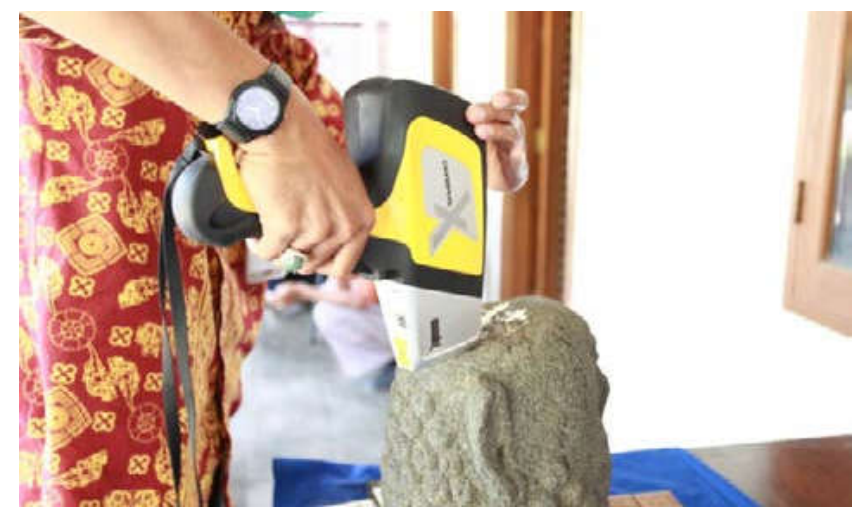

Foto 4. Pengukuran kandungan unsur menggunakan XRF (Dok: Tim kajian, 2015).
Seperti yang telah disampaikan di awal bahwa penyajian data pada pengukuran adalah dalam bentuk grafik perbandingan antara dua unsur. Dua unsur yang diperbandingkan tersebut adalah dua unsur teratas dengan nilai yang dominan atau lebih besar dari unsur lainnya. Adapun untuk pengukuran unsur material menggunakan XRF juga dilakukan pada tubuh arca, khususnya yang berada pada pagar langkan sejumlah 193 buah. Pengukuran dengan XRF tidak dilakukan pada tubuh arca yang berada pada stupa teras karena posisinya yang berada dalam stupa berlubang sehingga sulit diraih.

Sebagai contoh hasil pengukuran menggunakan XRF pada kepala arca no.1 sampai no.4 secara kasar adalah seperti disampaikan pada tabel berikut ini.

Tabel 12. Hasil Pengukuran Kandungan Unsur Material Kepala Arca Menggunakan XRF (dalam \%).

\begin{tabular}{|c|c|c|c|c|c|c|c|c|c|c|c|c|c|c|c|c|c|c|}
\hline $\begin{array}{c}\text { No } \\
\text { Kepala }\end{array}$ & Date & Reg & Al & $\mathrm{Si}$ & $\begin{array}{c}\mathrm{Si} \\
\text { Compound }\end{array}$ & $\underset{\substack{\text { Compound } \\
\text { Level }}}{\mid}$ & $\mathrm{Fe}$ & $\mathrm{Zr}$ & $\mathbf{A g}$ & Cd & Sn & Sb & $\mathrm{Pb}$ & s & $\mathrm{Cr}$ & Co & $\mathrm{Ni}$ & $\mathrm{Cu}$ \\
\hline \multirow[t]{3}{*}{1} & $30 / 07 / 2015$ & $\# 5$ & 7,25 & 22,59 & $\mathrm{SiO} 2$ & 48,32 & 4,27 & 0,0221 & 0183 & 0,0224 & 0,0098 & 0,0137 & 0,0036 & ND & ND & ND & ND & 0,0067 \\
\hline & $30 / 07 / 2015$ & \#6 & 6,93 & 21,73 & $\mathrm{SiO} 2$ & 46,49 & 4,7944 & 0,0221 & 0,0166 & 0,0241 & 0,01 & 0,0128 & 0,0042 & 0,1306 & ND & ND & ND & 0,0062 \\
\hline & $30 / 07 / 2015$ & $\# 7$ & 6,4 & 21,18 & $\mathrm{SiO} 2$ & 45,3 & 4,4821 & 0,0225 & 0,0172 & 0,0251 & 0,0104 & 0,0132 & 0,0065 & 0,0893 & ND & 0,0194 & ND & ND \\
\hline \multirow[t]{3}{*}{2} & $03 / 08 / 2015$ & \#2 & 8,29 & 22,37 & $\mathrm{SiO} 2$ & 47,85 & 4,9826 & 0,0202 & 0,0183 & 0,0261 & 0,0093 & 0,0131 & 0,0035 & 0,2556 & ND & ND & ND & ND \\
\hline & $03 / 08 / 2015$ & \#3 & 6,97 & 20,21 & $\mathrm{SiO} 2$ & 43,23 & 5,26 & 0,021 & 0,02 & 0,0275 & 0,0097 & 0,013 & 0,0029 & 0,3152 & ND & ND & ND & ND \\
\hline & $03 / 08 / 2015$ & $\# 4$ & 7,41 & 19,42 & $\mathrm{SiO} 2$ & 41,55 & 4,98 & 0,0213 & 0,0182 & 0,0281 & 0,0113 & 0,0114 & ND & 0,5054 & ND & ND & ND & ND \\
\hline \multirow[t]{3}{*}{3} & $03 / 08 / 2015$ & \#5 & 5,94 & 18,92 & $\mathrm{SiO} 2$ & 40,48 & 5,04 & 0,0215 & 0,0182 & 0,0272 & 0,0103 & 0,0121 & 0,0047 & 0,0644 & ND & ND & ND & ND \\
\hline & $03 / 08 / 2015$ & \#6 & 6,7 & 19,21 & $\mathrm{SiO} 2$ & 41,1 & 4,7 & 0,0236 & 0,0185 & 0,0284 & 0,0112 & 0,0136 & 0,0019 & ND & ND & ND & ND & ND \\
\hline & $03 / 08 / 2015$ & $\# 7$ & 5,63 & 17,06 & $\mathrm{SiO} 2$ & 36,5 & 5,12 & 0,0244 & 0,0197 & 0,0268 & 0,0101 & 0,0139 & 0,004 & 0,0801 & ND & 0,02 & ND & ND \\
\hline \multirow[t]{3}{*}{4} & $04 / 08 / 2015$ & \#2 & 7,18 & 22,37 & $\mathrm{SiO} 2$ & 47,84 & 4,0844 & 0,0209 & 0,0177 & 0,0219 & 0,0093 & 0,0131 & 0,0041 & 0,0933 & ND & ND & ND & ND \\
\hline & $04 / 08 / 2015$ & \#3 & 6,5 & 20,04 & $\mathrm{SiO} 2$ & 42,86 & 4,0126 & 0,0197 & 0,0194 & 0,0236 & 0,009 & 0,0126 & 0,0023 & 0,4991 & ND & ND & ND & ND \\
\hline & 04/08/2015 & \#4 & 7,04 & \begin{tabular}{|l|}
19,72 \\
\end{tabular} & $\mathrm{SiO} 2$ & 42,19 & 4,31 & 0,02 & 0,0193 & 0,0267 & 0,0099 & 0,0134 & 0,003 & 0,0755 & ND & ND & ND & ND \\
\hline
\end{tabular}

Ket :

$\mathrm{ND}=$ Not determine (tidak teridentifikasi) 


\subsection{Pengukuran Kandungan Magnetik Material Batu}

Pengukuran kandungan magnetik pada material kepala arca dan tubuh arca dilakukan dengan menggunakan alat magnetic susceptibility meter. Alat tersebut digunakan dengan cara menempelkan bagian muka dari alat magnetic susceptiility meter pada permukaan datar kepala arca maupun tubuh arca. Dari hasil pengukuran tersebut didapatkan satuan angka bervariasi yang kisaran minimumnya 5 dan maksimumnya 70. Hal ini menunjukkan bahwa kandungan magnetik pada material batu andesit sangat variatif, sehingga kemungkinan pencocokan kepala dan tubuh arca lebih besar.

Pengukuran kandungan magnetik pada kepala dan tubuh arca menggunakan magnetic susceptibility meter telah dilakukan pada $\mathbf{5 6}$ kepala dan $\mathbf{2 4 7}$ tubuh arca tanpa kepala. Metode pengukuran kandungan magnetik pada kepala maupun tubuh arca dilakukan sebanyak 6 kali pada tiap objek. Setelah didapatkan hasil pengukuran,maka langkah selanjutnya adalah membuat rata-rata dari ke-6 hasil pengukuran tersebut.

Pengukuran kandungan magnetik pada tubuh arca dilakukan pada arca Buddha yang tidak berkepala. Sebelum melakukan pengukuran, pemetaan posisi tubuh arca pada struktur Candi Borobudur harus jelas dan mendetail. Hal ini penting untuk menentukan posisi arca secara baku, sehingga pada saat pencocokan dapat dengan mudah

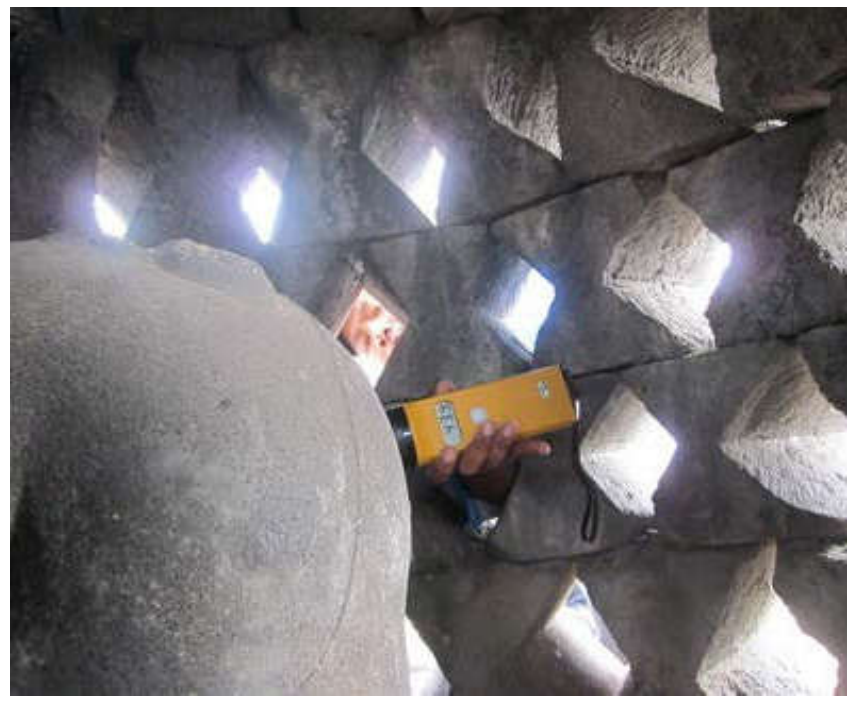

Foto 5. Pengukuran menggunakan magnetic susceptibility meter pada tubuh arca di dalam stupa teras (Dok: Tim kajian, 2015).

mengidentifikasi posisi tubuh arca pada struktur candi. Berikut ini adalah posisi tubuh arca Buddha dengan penomoran yang dimulai dengan nomor 1 pada tiap tingkatannya.

Hasil dari pengukuran kandungan magnetik material andesit pada tubuh arca terdiri dari satuan angka yang disusun pada tabel berdasarkan keletakan tubuh arca pada struktur Candi Borobudur.

Apabila dicermati sekilas beberapa pengukuran menunjukkan hasil yang mempunyai kecocokan seperti ditunjukkan pada grafik 1 dan 2 di bawah ini.

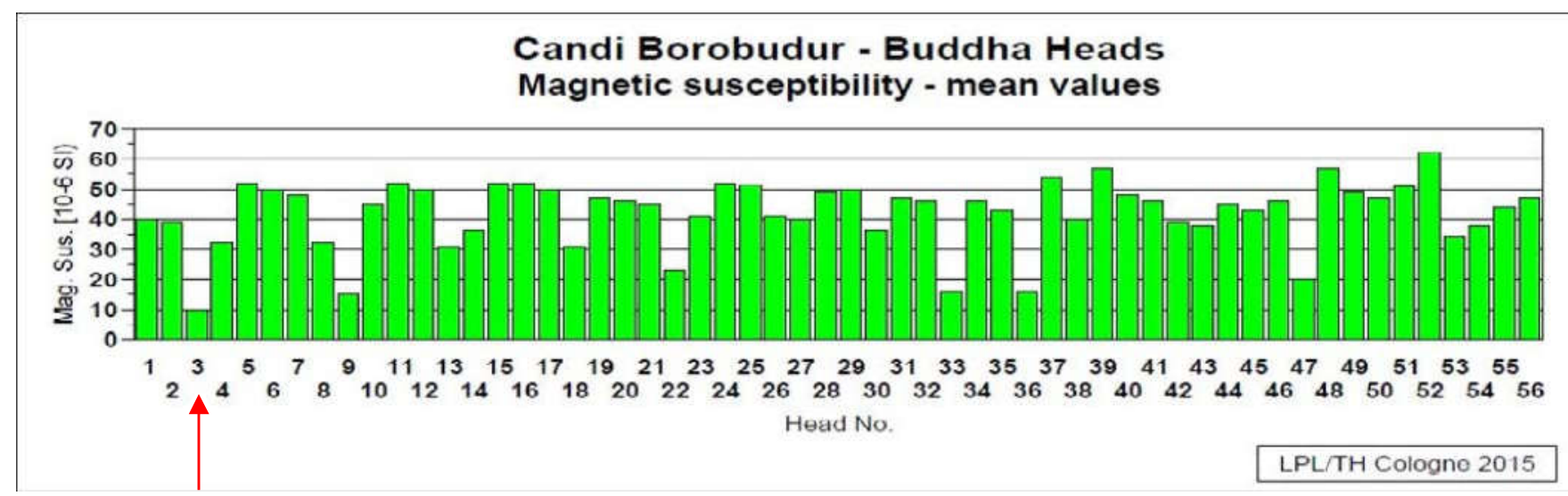

Grafik 1. Pengukuran kandungan magnetik pada kepala arca (tanda panah merupakan kepala arca dengan kandungan magnetik terendah). 


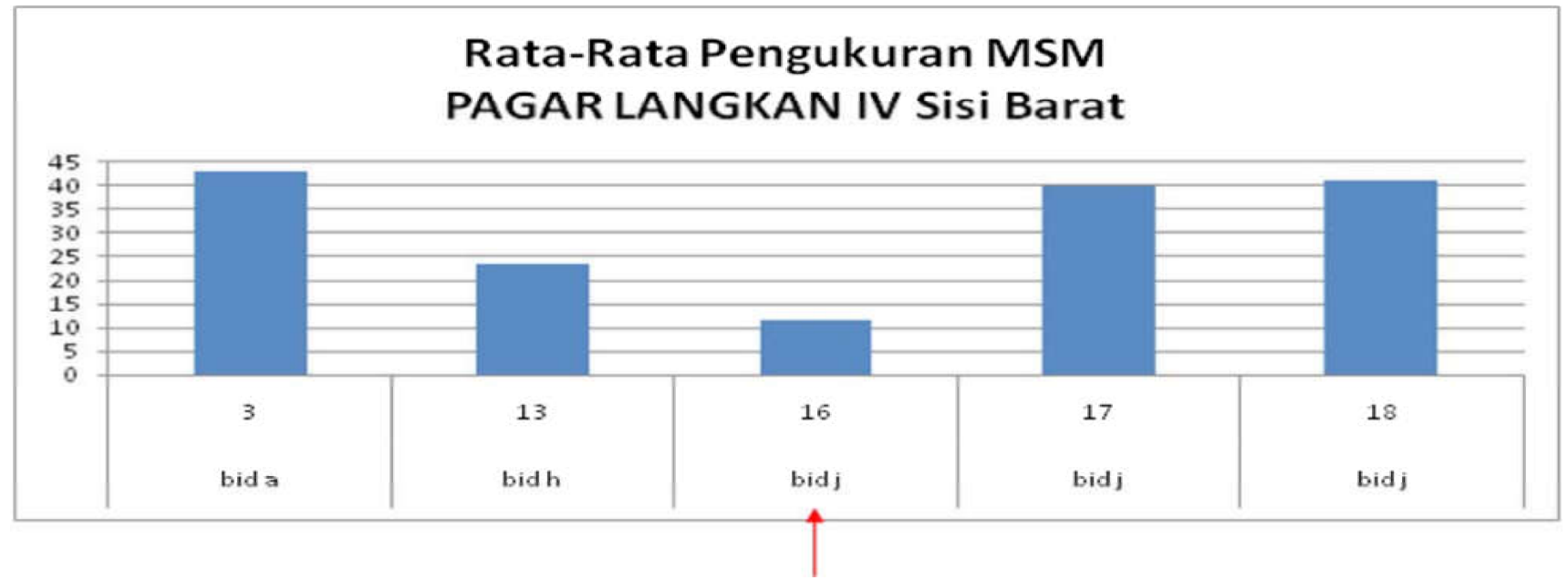

Grafik 2. Pengukuran kandungan magnetik tubuh arca pada pagar langkan IV sisi Barat (tanda panah merupakan kepala arca dengan kandungan magnetik terendah).

Berdasarkan grafik di atas, kepala arca no.3 memiliki kemungkinan yang lebih besar apabila dipasangkan dengan tubuh arca no.16 yang posisinya berada pada pagar langkan IV sisi Barat.

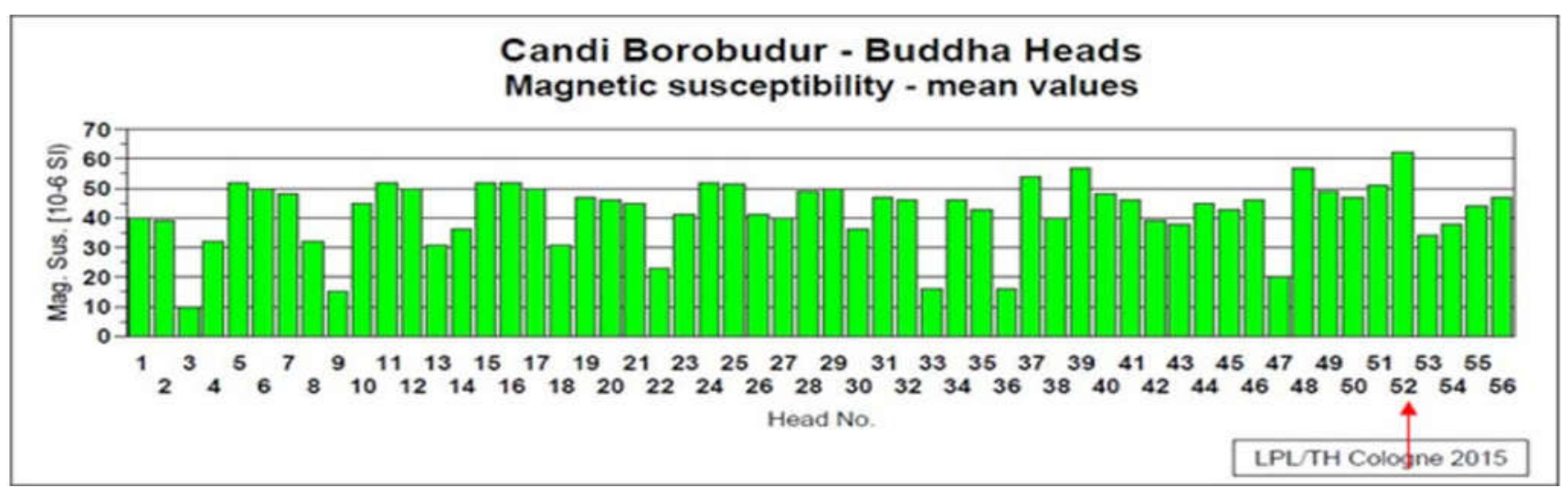

Grafik 3. Pengukuran kandungan magnetik pada kepala arca (tanda panah merupakan kepala arca dengan kandungan magnetik tertinggi).
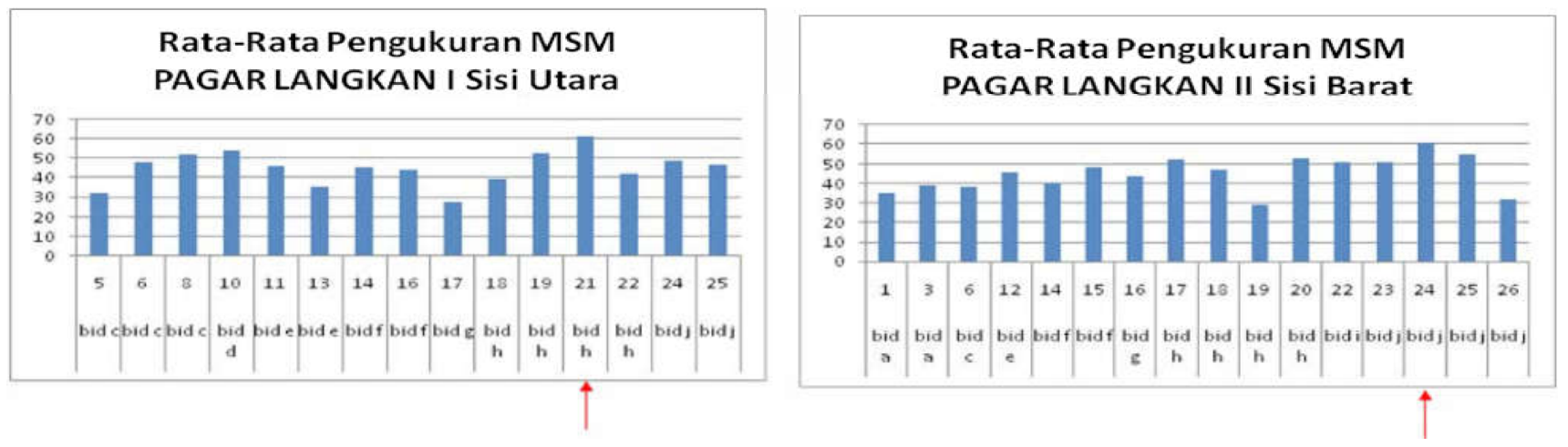

Grafik 4. Pengukuran kandungan magnetik tubuh arca pada pagar langkan I sisi Utara dan pagar langkan II sisi Barat (tanda panah merupakan kepala arca dengan kandungan magnetik tertinggi). 


\subsection{Pencocokan Menggunakan Tipologi Material} Batu Andesit

Pencocokan metode ini dilakukan dengan menetukan terlebih dahulu tipe material andesit pada kepala arca yang disimpan di Kantor Balai Konservasi Borobudur. Tipologi material kepala arca tersebut kemudian diformulasikan oleh Prof. Hans Liesens, seorang ahli geologi pada misi UNESCO untuk Borobudur. Setelah tipologi material ditentukan maka langkah selanjutnya adalah dengan melakukan pengamatan langsung terhadap material batu andesit pada tubuh arca yang berada pada struktur Candi Borobudur. Pengamatan material dan tipologi telah dilakukan pada 247 tubuh arca yang berada pada struktur candi. Setelah tipologi material pada semua arca tanpa kepala dapat ditentukan, maka langkah selanjutnya adalah mengelompokkan kepala dan tubuh arca sesuai dengan tipologinya.

Adapun tipologi material arca tersebut adalah sebagai berikut :

Tipe 1 : dark matrix, many very fine feldspar phenocrysts and very porous surface.

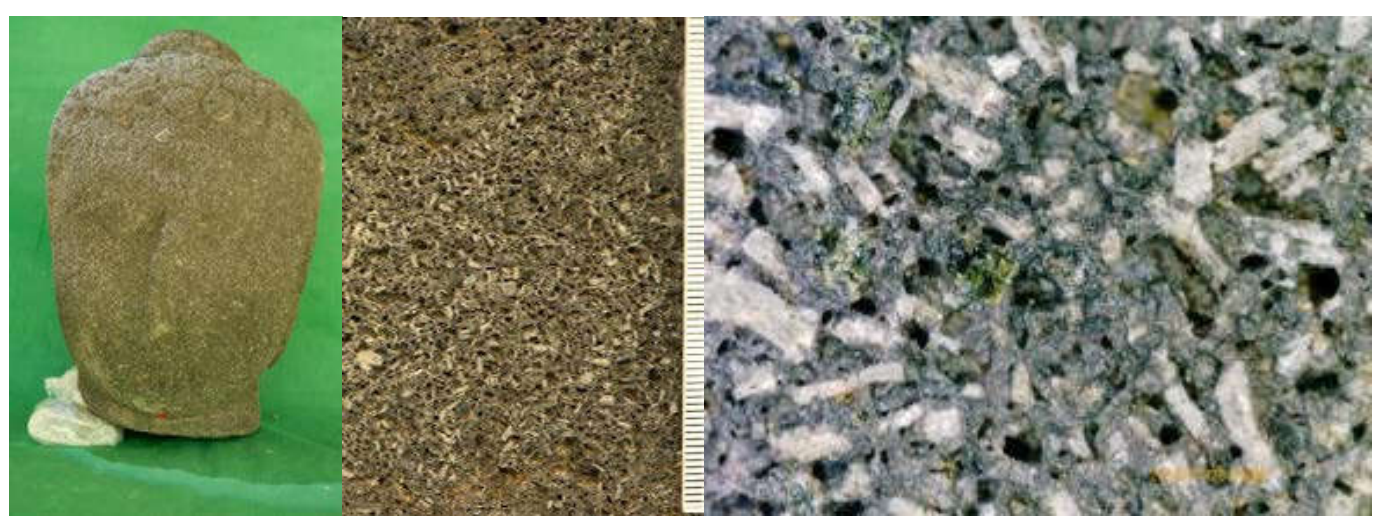

Foto 6. Material kepala arca tipe 1

Tipe 2 : dark matrix, bigger feldspar phenocrysts than type 1 and less porous texture.

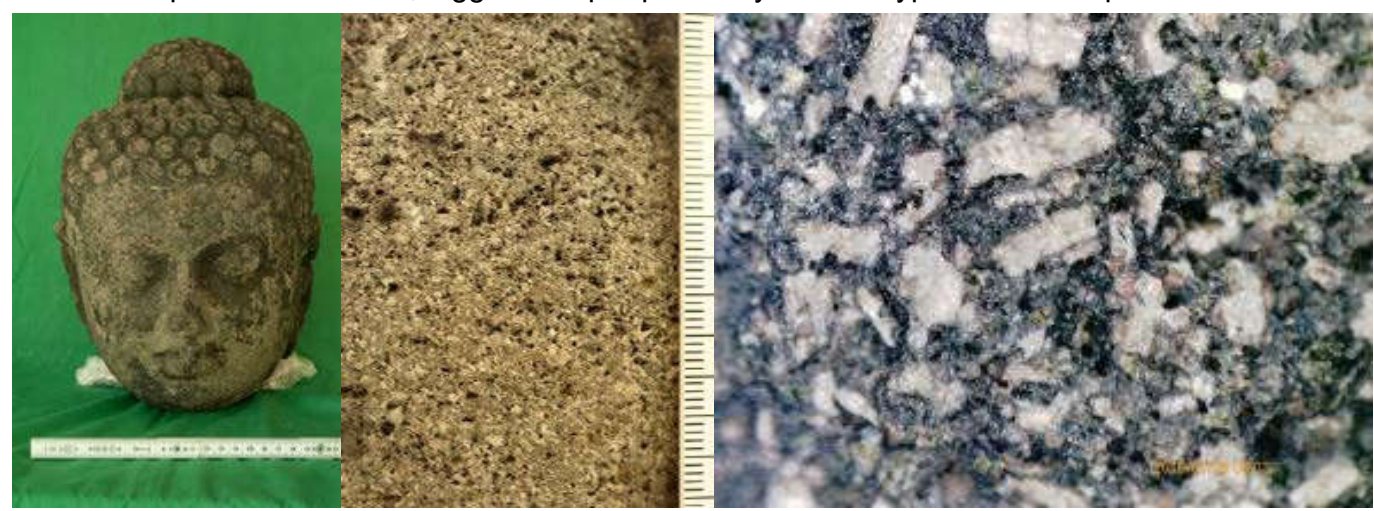

Foto 7 . Material kepala arca tipe 2 .

Tipe 3 : blue-grey matrix, dense texture, big mafic phenocrysts.
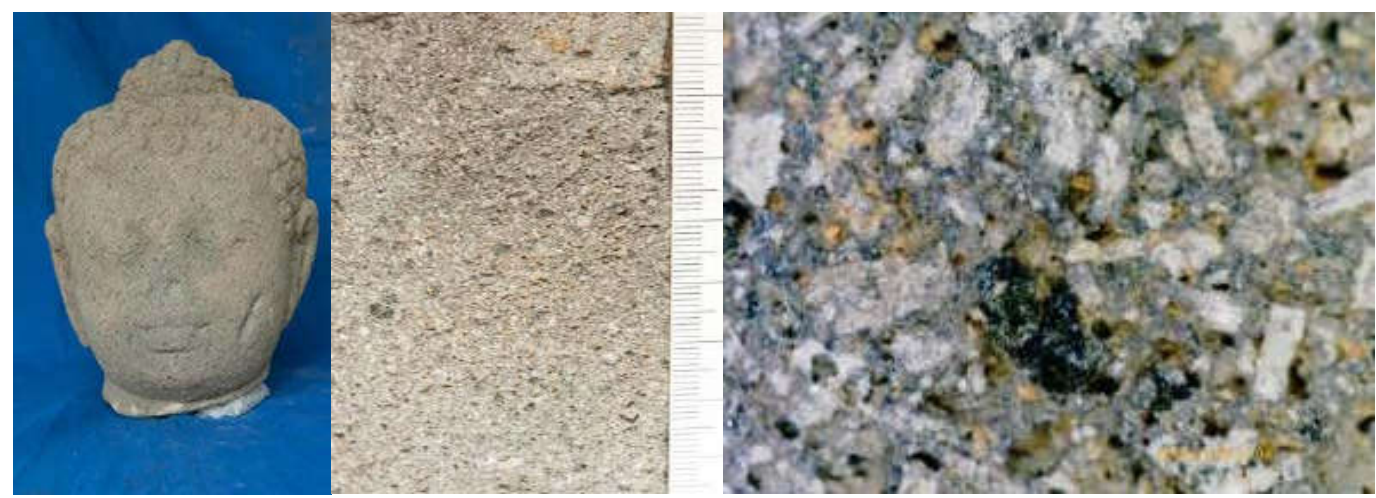

Foto 8. Material kepala arca tipe 3 . 
Tipe 4 : dark grey, feldspars granular texture.
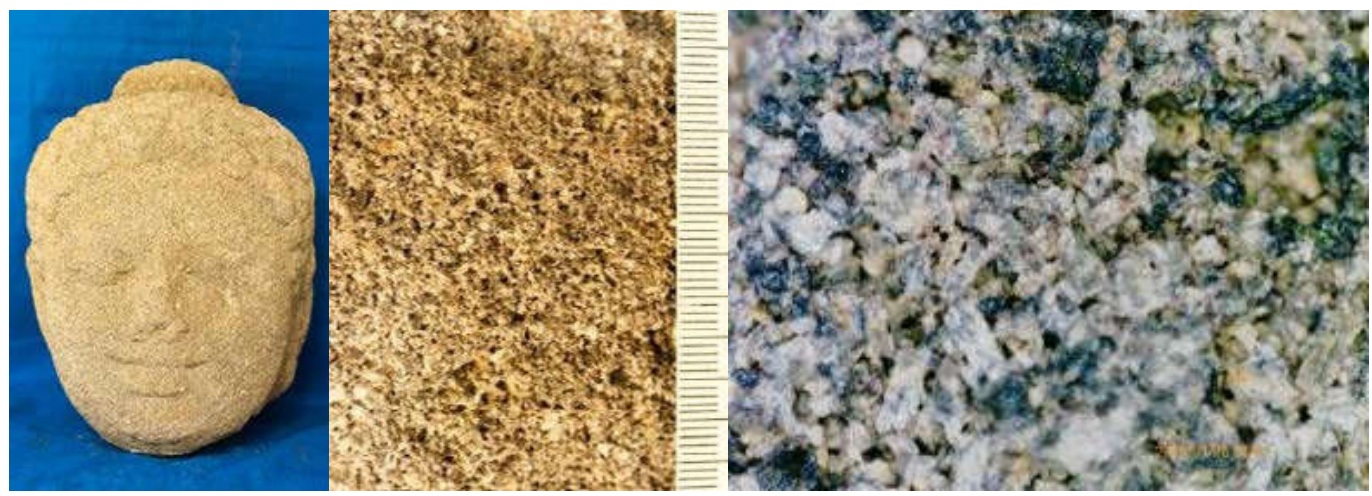

Foto 9. Material kepala arca tipe 4.

Tipe 5 : dark matrix, only few phenocrysts, very compact.
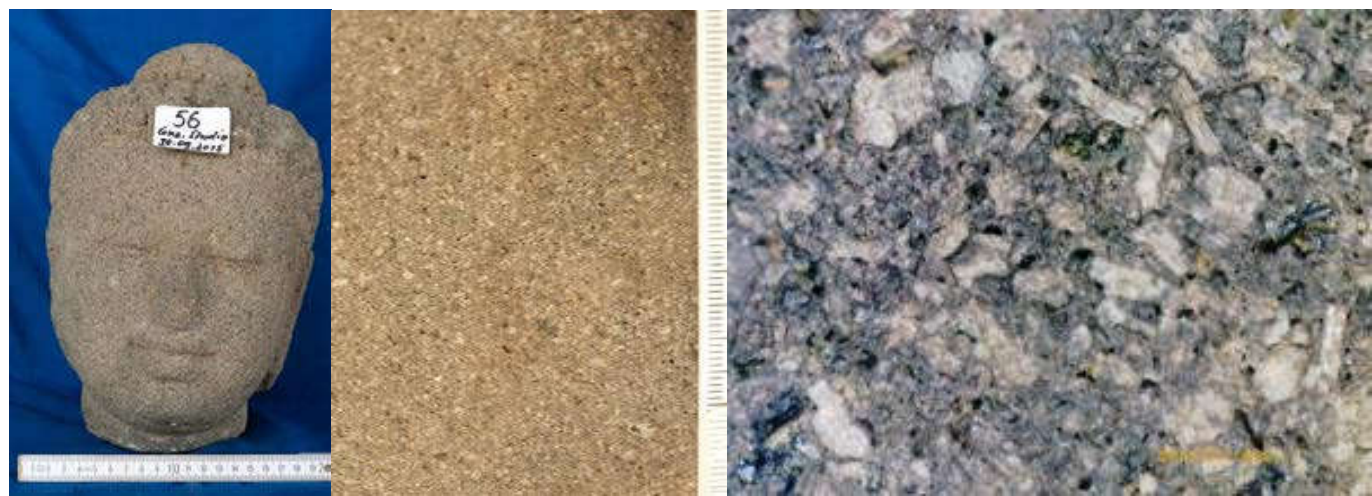

Foto 10. Material kepala arca tipe 5.

Tipe 6 : brown to light colour, porous

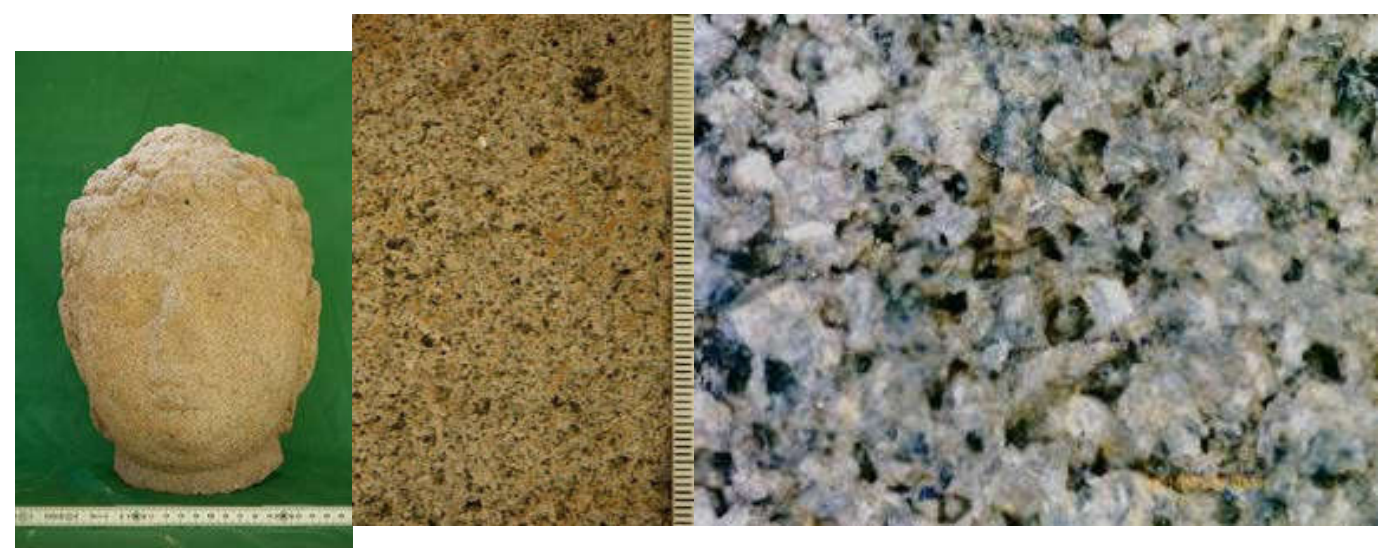

Foto 11. Material kepala arca tipe 6.

Pencocokan menggunakan metode tipologi material batu andesit diharapkan memiliki prospek untuk pencocokan yang lebih baik dibandingkan dengan metode yang lain. Namun demikian pencocokan menggunakan metode ini harus di perkuat dengan data yang lain, salah satunya adalah data XRF pada kepala dan tubuh arca. Berikut ini adalah data tipologi material batu andesit kepala dan tubuh arca Dhyani Buddha Candi Borobudur. 
Tabel 13. Jumlah populasi dari tipologi berdasarkan tipe material kepala dan tubuh arca.

\begin{tabular}{|c|l|c|c|}
\hline \multirow{2}{*}{ Tipe } & \multicolumn{1}{|c}{ Deskripsi } & \multicolumn{2}{c|}{ Jumlah } \\
\cline { 3 - 4 } & \multicolumn{1}{|c|}{$\begin{array}{c}\text { Kepala arca } \\
\text { dark matrix, many very fine feldspar phenocrysts and very } \\
\text { porous surface }\end{array}$} & 18 & 45 \\
\hline 2 & $\begin{array}{l}\text { dark matrix, bigger feldspar phenocrysts than type 1 and less } \\
\text { porous texture }\end{array}$ & 18 & 83 \\
\hline 3 & blue-grey matrix, dense texture, big mafic phenocrysts & 11 & 41 \\
\hline 4 & dark grey, feldspars granular texture & 4 & 41 \\
\hline 5 & dark matrix, only few phenocrysts, very compact & 4 & 57 \\
\hline 6 & brown to light colour, porous & 9 & 14 \\
\hline
\end{tabular}

\section{ANALISA}

\subsection{Pencocokan Kepala Dengan Tubuh Arca}

Setelah didapatkan data dari berbagai metode pencocokan di atas, langkah selanjutnya kemudian mengkompilasi, melakukan cross-check data, dan mencobakannya di lapangan.

Metode ultrasound velocity dinilai susah diaplikasikan karena cepat rambat gelombang hampir sama pada setiap kepala arca.

Adapun metode pengukuran ikonometri juga mencapai hal yang serupa dengan metode ultrasound velocity. Hal ini karena, setelah dilakukannya pengukuran ikonometri pada semua kepala arca dan tubuh arca pada pagar langkan I, ternyata hasil pengukuran menunjukkan kemiripan. Sehingga antara 1 kepala dengan kepala arca yang lain ukurannya sangat presisi pada ukuran/ ikonometrinya. Hal yang demikian juga terjadi pada pengukuran tubuh arca. Maka berdasarkan data ikonometri, kemungkinan pencocokan dengan metode tersebut sangat kecil.

Metode pencocokan dengan menggunakan ikonografi detil dari bentuk penggambaran profil kepala Buddha dengan atributnya belum pernah dicoba sebelumnya. Ikonografi kepala arca secara detil, dalam hal ini menyangkut bentuk penggambaran komponen wajah pada kepala arca. Misalnya bentuk hidung, mata, telinga, maupun urna. Metode ini akan mengamati ikonografi arca Buddha yang kepalanya masih menyatu dengan tubuhnya dan berada pada pagar langkan maupun stupa teras.

\subsection{Pencocokan Menggunakan Metode Magnetic} Susceptibility.

Pencocokan dengan metode magnetic susceptibility dilakukan dengan mencari kandungan magnetik yang terendah maupun yang tertinggi pada kepala dan tubuh arca. Akan tetapi setelah di cross check dengan metode tekstur/tipe material arca ternyata sangat jauh hasilnya. Sebagai contoh pada kepala arca no. 52 masuk dalam tipe material 5, seharusnya dia cocok dengan tubuh arca yang sama tipe materialnya. Namun demikian data di lapangan menunjukkan bahwa kepala arca no.52 kandungan magnetiknya nilainya sama dengan tubuh arca pada pagar langkan I Utara no.21 dan pagal langkan II Barat no. 24 yang keduanya tipe materialnya bukan dari tipe 5. Hal ini dapat dimengerti bahwa dimungkinkan posisi tubuh arca yang terekspos langsung dengan lingkungan karena masih berada pada struktur candi memiliki tingkat pelapukan yang lebih tinggi dari kepala arca yang disimpan dalam ruangan. Sehingga hasil pengukuran kandungan magnetiknya harus mempertimbangkan proses pelapukan.

\subsection{Pencocokan Menggunakan Metode Tipe}

\section{Material dan XRF}

Pendekatan tipe material adalah salah satu metode pencocokan yang dimulai dengan mengelompokkan semua kepala arca dan tubuh arca Dhyani Buddha Candi Borobudur ke dalam 6 tipe. Keenam tipe tersebut dikelompokkan berdasarkan tekstur batu andesit yang digunakan sebagai bahan 
arca. Pendekatan tipologi material juga didasarkan prinsip pembatan arca batu yang menggunakan batu yang monolith dan utuh tanpa sambungan. Berikut ini adalah tipologi material kepala dan tubuh arca Dhyani Buddha Candi Borobudur.

Tabel 14. Tipologi kepala arca Dhyani Buddha Candi Borobudur (Liesens, 2015).

\begin{tabular}{|c|c|c|c|c|c|}
\hline \multicolumn{6}{|c|}{ Tentative Visual Grouping of Buddha Head Stone Types } \\
\hline Type 1 & Type 2 & Type 3 & Type 4 & Type 5 & Type 6 \\
\hline 1 & 3 & 2 & 19 & 12 & 2 \\
\hline 4 & 7 & 5 & 36 & 24 & 5 \\
\hline 6 & 11 & 20 & 46 & 44 & 9 \\
\hline 8 & 14 & 26 & 47 & 52 & 10 \\
\hline 17 & 15 & 27 & & & 13 \\
\hline 18 & 16 & 31 & & & 19 \\
\hline 21 & 24 & 37 & & & 22 \\
\hline 23 & 29 & 48 & & & 33 \\
\hline 25 & 30 & 50 & & & 56 \\
\hline 28 & 32 & 56 & & & \\
\hline 34 & 38 & & & & \\
\hline 35 & 39 & & & & \\
\hline 38 & 40 & & & & \\
\hline 40 & 41 & & & & \\
\hline 42 & 49 & & & & \\
\hline 43 & 53 & & & & \\
\hline 51 & 54 & & & & \\
\hline 55 & 55 & & & & \\
\hline
\end{tabular}

Ket : Warna kuning adalah kepala arca yang masuk dalam dua tipe atau lebih.

Pencocokan dari tekstur material arca yang kemudian ditetapkan dalam pengelompkkan (tipe 1-6) merupakan metode yang diharapkan dapat memperbesar kemungkinan pencocokan yang kemudian diperkuat dengan data XRF. Berikut ini adalah hasil tipologi material tubuh arca pada stuktur Candi Borobudur yang ditetapkan berdasarkan tipologi pada kepala arca.

Pencocokan dengan metode kemudian mengerucut dengan mengecek terlebih dahulu kepala dan tubuh arca yang masuk tipe 6. Hal ini karena tipe 6 mempunyai populasi paling sedikit. Berikut ini adalah kepala dan tubuh arca yang masuk tipe 6 .

Untuk mengetahui efektifitasnya, metode ini kemudian ditindaklanjuti dengan melihat data XRF kepala dan tubuh arca tipe 6. Setelah melihat data XRF dan mencermatinya kemudian dicatat indikasi kecocokan pada tipe ke 6 yaitu pada kepala no.10, 22, dan 33 dengan tubuh no. 12 sisi Timur pagar langkan I dan tubuh no, 1 sisi Barat pagar langkan III. Berdasarkan temuan tersebut selanjutnya dilakukan pencocokan secara langsung dengan membawa kepala arca no.33, 10, 22 untuk dicocokkan dengan ke 14 tubuh arca. Berikut ini adalah data fotografi dari pencocokan langsung kepala arca dengan tubuh arca pada tipe yang ke-6.

Tabel 15. Kepala dan tubuh Arca Buddha dengan tipe 6.

\begin{tabular}{|c|c|c|c|c|c|}
\hline \multirow{2}{*}{ Tipe } & \multirow{2}{*}{$\begin{array}{c}\text { No } \\
\text { Kepala }\end{array}$} & \multicolumn{4}{|c|}{ Tubuh } \\
\hline & & No & Sisi & Bidang & Posisi \\
\hline \multirow[t]{14}{*}{6} & 2 & 12 & Timur & e & Pagar langkan I \\
\hline & 5 & 22 & Timur & $\mathrm{h}$ & Pagar langkan I \\
\hline & 9 & 26 & Timur & j & Pagar langkan I \\
\hline & 10 & 14 & Timur & $f$ & Pagar langkan II \\
\hline & 13 & 1 & Barat & a & Pagar langkan II \\
\hline & 19 & 18 & Barat & $\mathrm{h}$ & Pagar langkan II \\
\hline & 22 & 10 & Utara & c & Pagar langkan II \\
\hline & 33 & 11 & Timur & e & Pagar langkan III \\
\hline & 56 & 1 & Barat & a & Pagar langkan III \\
\hline & & 15 & Utara & $\mathrm{h}$ & Pagar langkan III \\
\hline & & 3 & Barat & a & Pagar langkan IV \\
\hline & & 14 & Utara & $\mathrm{i}$ & Pagar langkan IV \\
\hline & & 7 & & & Teras III \\
\hline & & 18 & & & Teras II \\
\hline
\end{tabular}

Berikut ini adalah pelaksanaan pencocokan kepala dengan tubuh arca menggunakan metode pendekatan tipe material yang diperkuat menggunakan data XRF. Tipe material andesit yang digunakan untuk dicocokkan adalah pada tipe ke 6, karena populasi yang paling sedikit. 
Pencocokan kepala arca no. 10 dengan badan Sisi Barat Pagar langan III bidang a no. 1
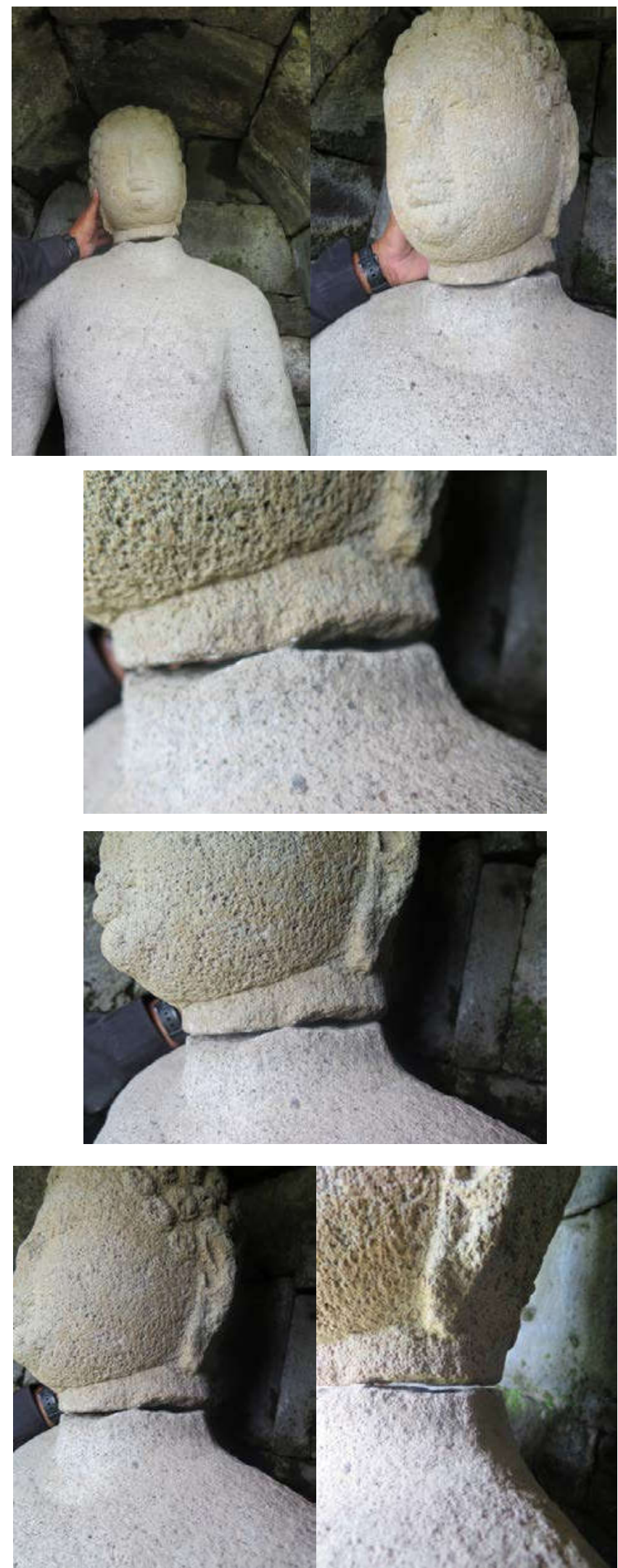

Foto 12. Pencocokankepala arca Dhyani Buddha Candi Borobudur no.10 denganbadan Sisi Barat Pagar langan III bidang a no. 1
Pencocokan kepala arca no. 33 dengan badan Sisi Timur Pagar langan I bidang e no. 12.
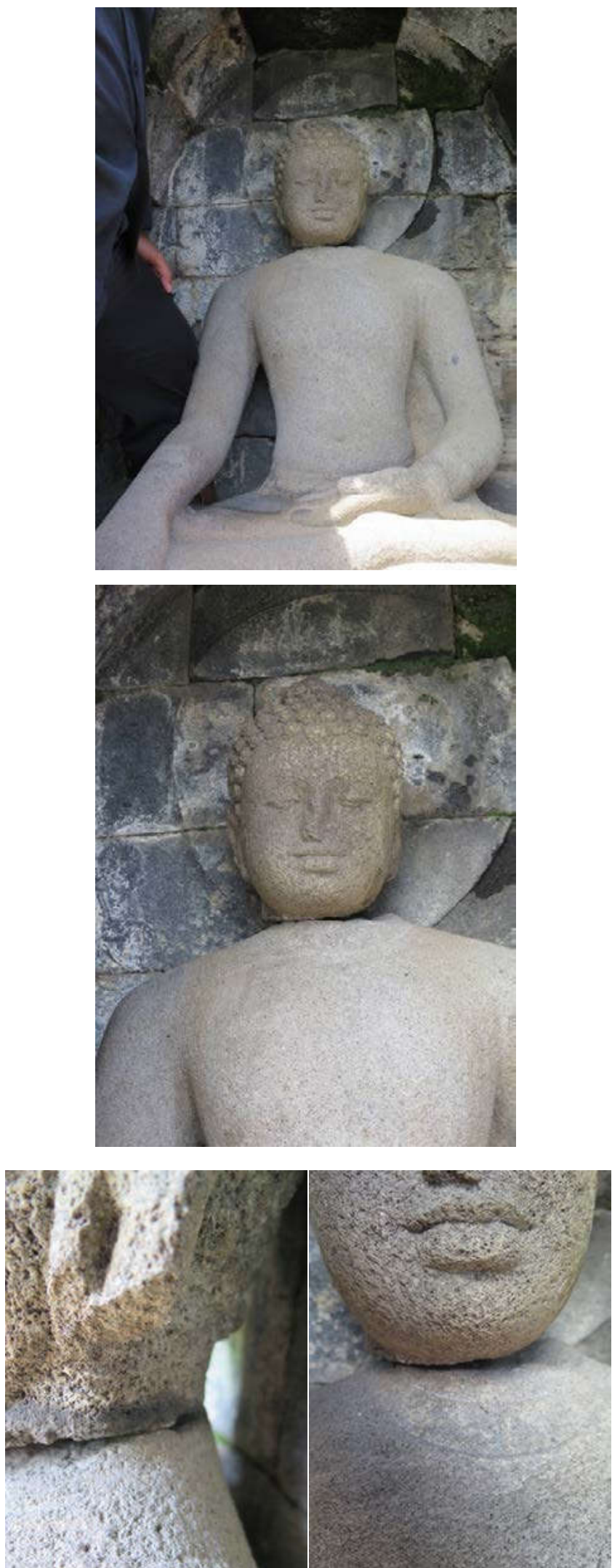

Foto 13. Kepala arca Dhyani Buddha Candi Borobudur no.33 dengan badan Sisi Timur Pagar langan I bidang e no. 12. 
Berdasarkan pendetailan data XRF pada tipe material ke-6, kepala no.33 mempunyai indikasi kecocokan yang kuat dengan tubuh arca pada sisi Timur pagar langkan I no.12. Adapun kepala arca no.10 mempunyai indikasi kecocokan yang kuat dengan tubuh arca pada sisi Barat pagar langkan III no.1.

Tabel 16. XRF pada tubuh arca dengan indikasi kuat bisa dicocokkan.

\begin{tabular}{|c|c|c|c|c|c|c|c|c|c|c|c|c|}
\hline $\begin{array}{c}\text { No. } \\
\text { Tubuh }\end{array}$ & $\mathrm{Al}$ & $\mathrm{Si}$ & $\mathrm{SiO} 2$ & $\mathrm{P}$ & $\mathrm{S}$ & $\mathrm{K}$ & $\mathrm{Ca}$ & $\mathrm{Ti}$ & $\mathrm{V}$ & $\mathrm{Cr}$ & $\mathrm{Mn}$ & $\mathrm{Fe}$ \\
\hline I Barat & 6,43 & 20,80 & 44,49 & 0,12 & 0,06 & 2,13 & 4,29 & 0,51 & 0,06 & 0,02 & 0,14 & 4,88 \\
\hline 12 Timur & 7,44 & 20,37 & 43,58 & 0,06 & 0,06 & 1,51 & 4,46 & 0,65 & 0,07 & 0,02 & 0,14 & 6,26 \\
\hline $\begin{array}{c}\text { No. } \\
\text { Tubuh }\end{array}$ & $\mathrm{Co}$ & $\mathrm{Ni}$ & $\mathrm{Cu}$ & $\mathrm{Zn}$ & $\mathrm{Zr}$ & $\mathrm{Ag}$ & $\mathrm{Cd}$ & $\mathrm{Sn}$ & $\mathrm{Sb}$ & $\mathrm{W}$ & $\mathrm{Pb}$ & $\mathrm{Bi}$ \\
\hline I Barat & 0,01 & $\mathrm{ND}$ & 0,01 & 0,01 & 0,02 & 0,02 & 0,03 & 0,01 & 0,01 & 0,00 & 0,00 & 0,00 \\
\hline 12 Timur & 0,01 & 0,00 & 0,01 & 0,05 & 0,02 & 0,02 & 0,03 & 0,01 & 0,01 & 0,00 & 0,00 & 0,00 \\
\hline
\end{tabular}

Tabel 17. XRF pada kepala arca dengan indikasi kuat bisa dicocokkan.

\begin{tabular}{|c|c|c|c|c|c|c|c|c|c|c|c|c|}
\hline $\begin{array}{c}\text { No. } \\
\text { Kepala }\end{array}$ & Al & $\mathrm{Si}$ & $\mathrm{SiO} 2$ & $P$ & $S$ & $\mathrm{~K}$ & $\mathrm{Ca}$ & $\mathrm{Ti}$ & V & $\mathrm{Cr}$ & $\mathrm{Mn}$ & $\mathrm{Fe}$ \\
\hline 33 & 3,21 & 25,63 & 54,82 & 0,02 & 0,15 & 0,97 & 3,52 & 0,42 & 0,06 & 0,02 & 0,13 & 4,57 \\
\hline 10 & 6,56 & 20,72 & 44,33 & 0,03 & 0,03 & 1,33 & 3,82 & 0,47 & 0,05 & 0,02 & 0,14 & 4,52 \\
\hline & $\begin{array}{l}\text { No. } \\
\text { Kepala }\end{array}$ & Co & $\mathrm{Cu}$ & $\mathrm{Zn}$ & $\mathrm{Zr}$ & $\mathrm{Ag}$ & $\mathrm{Cd}$ & $\mathrm{Sn}$ & $\mathrm{Sb}$ & $\mathrm{Pb}$ & $\mathrm{Bi}$ & \\
\hline & 33 & 0,01 & 0,01 & 0,01 & 0,02 & 0,02 & 0,03 & 0,01 & 0,01 & 0,00 & 0,00 & \\
\hline & 10 & 0,01 & ND & 0,01 & 0,02 & 0,02 & 0,03 & 0,01 & 0,01 & 0,00 & ND & \\
\hline
\end{tabular}

\section{KESIMPULAN}

Berdasarkan hasil analisa Kajian Pencocokan Kepala Arca Buddha Candi Borobudur Tahap II yang menggunakan metode pencocokan berdasarkan tipe material dapat disampaikan kesimpulan sebagai berikut :

a. Berdasarkan pendetailan data XRF pada tipe material ke-6, kepala no.33 mempunyai indikasi kecocokan yang kuat dengan tubuh arca pada sisi Timur pagar langkan I no.12. Adapun kepala arca no.10 mempunyai indikasi kecocokan yang kuat dengan tubuh arca pada sisi Barat pagar langkan III no.1.

b. Dari hasil Kajian Pencocokan kepala Arca Buddha Candi Borobudur Tahap II dapat diketahui prospek metode pencocokan tipe material yang diperkuat dengan data XRF dapat dilanjutkan kembali pada tipe material dengan c. populasi terendah yaitu tipe ke-6.

d. Berdasarkan hasil pencocokan pada kedua kepala arca seperti yang disampaikan pada point "a" di atas maka kemungkinan besar material arca sama namun warna dan tingkat pelapukan antara arca dan tubuh arca tersebut berbeda. Hal ini karena kepala arca disimpan di dalam ruangan dengan suhu yang dikendalikan, sedangkan pada tubuh arca pada struktur candi cenderung mengalami pelapukan yang lebih cepat. 


\section{DAFTAR PUSTAKA}

Casparis, J. G. de. 1950. Prasasti Indonesia I. Bandung: A.C. Nix \& Co.

Leisen, Hans.,Esther von Plehwe. 2016. Report in Technical Mission to Borobudur World Heritage Site in Indonesia September 20th to October 3rd 2015.

Leliek A. Haldoko, dkk. Kajian Karakteristik Jenis-Jenis Batu Penyusun Candi Borobudur, Magelang : Balai Konservasi Borobudur.

Maulana, Ratnaesih. 1997. Ikonografi Hindhu. Jakarta: Fakultas Sastra Universitas Indonesia.

Muryowiharjo, S., 2005, Petrografi Batuan Beku, Jurusan Teknik Geologi UGM, Yogyakarta.
Rao, T.A Gopinatha. 1920. Talamana Of Iconometri. Memoirs of The Archaeological Survei of India, 3. Calcuta.

Setyawan, Hari.dkk. 2015. Kajian Pencocokan Kepala Arca Buddha Candi Borobudur (Tahap I). Borobudur: Laporan Kajian Balai Konservasi Borobudur.

W. F. Stuterheim. 1950. Chandi Borobudur Name Form and Meaning, Studies In Indonesia Archaeology. Batavia: Kolff \& Co. 